\title{
EMPLOYED PROFESSIONALS' ETHICAL RESPONSIBILITIES IN PUBLIC SERVICE AND PRIVATE ENTERPRISE: DILEMMA, PRIORITY AND SYNTHESIS
}

\author{
HUGH BREAKEY* AND CHARLES SAMPFORD**
}

\section{INTRODUCTION}

Traditionally, most professionals operated as sole practitioners or in small partnerships. ${ }^{1}$ This work environment affected professions' images of themselves and the way their ethics was conceived and written. But the locus of practice has changed and is continuing to change. ${ }^{2}$ Though the common image of professionals remains of sole practitioners serving individual clients on a one-toone basis, many of the most senior professionals work within large organisations. These organisational environments may be characterised by intense competition for work and/or clients both within and between organisations. Instead of a professional enjoying security of occupation and income, and wide professional autonomy, he or she may be placed in contexts that are large, competitive, teambased, and/or multidisciplinary, where work is unbundled and spread around,

* $\quad$ Research Fellow, Institute for Ethics, Governance and Law (IEGL), Law Futures Centre, Griffith University. (Correspondence: h.breakey@griffith.edu.au)

** Director IEGL and Foundation Dean and Professor of Law and Research Professor in Ethics, Griffith University. Adjunct Professor, Strathmore, Queensland University of Technology and York University. The authors acknowledge the support of the Australian Research Council and the Professional Standards Councils for this work. They are also grateful for the support of professional partners to the grant, law firms Allens and Corrs Chambers Westgarth. The authors also acknowledge the support of the Centre for Law Markets and Regulation at UNSW Law and the Law Futures Centre, Griffith University for this work.

1 This is especially true of lawyers and doctors. The third traditional 'learned' profession (the clergy) generally served within a large organisation, with degrees of autonomy that varied with denomination.

2 Doctors' practices are increasing in size, reach and form. They may be contracted to practices, to a chain of medical centres, to health providers, or to corporations. An increasing number work for large hospitals, who are also the major employer of nurses. Lawyers are also increasingly employed by large organisations. As well as their many roles in government, lawyers practice in corporations and, increasingly, in mega-practices which are incorporated and even listed on the stock exchange. Journalists have long worked for large and powerful organisations (something necessitated by the costs of printing presses), though these have continued to increase in size. Teachers and engineers can similarly find themselves employed by large organisations, as can those service providers (like bankers and financial advisers) that have professional aspirations. For literature on the shifts in professions over the last two decades, see Frans Bévort and Roy Suddaby, 'Scripting Professional Identities: How Individuals Make Sense of Contradictory Institutional Logics' (2015) 3 Journal of Professions and Organization 17, 17-18, 22. 
creating situations of low decision latitude and unclear lines of responsibility. The employing organisation may even usurp traditional professional organisation tasks, including socialisation, education, training, self-regulation, lobbying and fostering a sense of identity. In this environment, professionals can seem to face 'multiple duties [which] need to be deciphered and weighed against each other' and may have to 'reconcile the ascendance of commercial considerations over older notions of professionalism'. ${ }^{3}$

As more professionals are employed by large organisations, there is a risk that they and their employers may think they must prioritise what are seen, or prescribed, to be the organisation's values, goals and ethics - even if these clash with their professional ethics. Consider a striking case regarding the ethics of government-employed lawyers: In the lead-up to the North Atlantic Treaty Organization's ('NATO') intervention in Kosovo in 1999, the United Kingdom ('UK') was concerned about the legality of the proposed military action. ${ }^{4}$ As James Rubin recounts, the UK Foreign Secretary Robin Cook was reluctant to act because his lawyers had advised that the war would be illegal. ${ }^{5}$ In response, Madeleine Albright, the US Secretary of State, brusquely advised him to 'get new lawyers'. ${ }^{6}$ Soon enough, new lawyers were found who, unlike the first lawyer, was prepared to disagree with the vast majority of international lawyers.

This case provides a vivid illustration of a powerful employer - a sovereign state - desiring a specific result from its professional employees, irrespective of their professional obligations. The situation presents a hard test of professional ethics, because of the unlikelihood of such a case ever coming before a court of competent jurisdiction (in this case, the International Court of Justice). Stripped of the possibility of external, objective judgment, the only thing standing in the way of the employer getting their desired result was the employee's professional ethic - in this case, the lawyer's requirement to faithfully represent the act's legal status. In the event, the relevant lawyer tried his very best to find a way to legally justify the planned bombing, but could not do so. He demonstrated independence, integrity and courage in advising his superiors of this conclusion.

Similar issues replayed in later years, including in the Iraq War of 2003, where senior government lawyers appeared to shift their positions in perplexing, yet pro-government, directions - even as countries stepped away from the jurisdiction of the relevant courts. ${ }^{7}$ As this article goes to print, the current cause

3 Chief Justice Marilyn Warren, 'Legal Ethics in the Era of Big Business, Globalisation and Consumerism' (Remarks delivered at the Joint Law Societies Ethics Forum, Melbourne, 20 May 2010).

4 For in-depth discussion and explanation, see Charles Sampford, 'Get New Lawyers!' (2003) 6 Legal Ethics 85; Charles Sampford, 'More and More Lawyers but Still No Judges' (2005) 8 Legal Ethics 16; Charles Sampford, 'Legality and Legitimacy: A Dozen Years after Goldstone' in Charles Sampford and Ramesh Thakur (eds), Responsibility to Protect and Sovereignty (Ashgate, 2013) 143.

5 Sampford, 'More and More Lawyers, above n 4, 16.

6 Ibid.

7 Sampford, 'More and More Lawyers', above n 4. Rosen notes that the timing of the involvement of counsel can be pivotal in such cases. When clients have already committed to an organisational initiative, they will resist legal constraints at the eleventh hour: Robert Eli Rosen, 'Problem-Setting and Serving the Organizational Client: Legal Diagnosis and Professional Independence' (2001) 56 University of Miami Law Review 179, 205-6. 
celebre is President Trump's sacking of United States ('US') Acting AttorneyGeneral Sally Yates because she did not consider the President's travel ban on seven Muslim-majority countries as constitutional, and had instructed Department of Justice lawyers to cease arguing that it was. While all details are not yet available, it is fair to assume that she was cognisant of Rule 3.1 of the American Bar Association Rules:

A lawyer shall not bring or defend a proceeding, or assert or controvert an issue therein, unless there is a basis in law and fact for doing so that is not frivolous, which includes a good faith argument for an extension, modification or reversal of existing law. ${ }^{8}$

The importance of such independence was emphasised by none other than then-Senator and Trump's nominee for Attorney-General, Jeff Sessions, at Yates' 2015 confirmation hearings. ${ }^{9}$ Sessions asked, 'Do you think the attorney general has a responsibility to say no to the president if he asks for something that's improper ...?' In reply, Ms Yates declared: 'I believe the attorney general or the deputy attorney general has an obligation to follow the law and the constitution and to give their independent legal advice to the president'.

While such cases as these are becoming more prevalent, they are not new. Macaulay's famous 1832 essay on Francis Bacon lampooned the lawyer as a man who would, 'with a wig on his head, and a band round his neck, do for a guinea what, without those appendages, he would think it wicked and infamous to do for an empire'. ${ }^{10}$ Macaulay was speaking of a lawyer who worked for an employer far more powerful than any modern law firm, litigation funder or multinational corporation: Francis Bacon worked as a QC and judge for Elizabeth I and James I/VI.

With such cases as these in mind, this article explores two research questions: First, are there at least prima facie tensions between professional ethics and the ethics of the large organisational employer (whether corporate or government)? Second, if such tensions do exist, how can they be appropriately resolved?

After stipulating some definitions and terminological choices, we begin by outlining the nature of professional ethics (Part I) and consider the ways in which adding a large organisation as employer to the mix can impact upon those ethics (Part II). Part III then considers the first research question, and provides an affirmative answer. We argue that - while many synergies lie between professional, corporate and public service ethics - there can be at least prima facie tensions between each ethic's overall nature, specific obligations and broad values. With this tension laid down, Part IV enquires into the second research question. In order to resolve the potential tension between professional, private and public ethics, we return to first principles, and consider how the three

8 American Bar Association, Model Rules of Professional Conduct (2016) <http://www.americanbar.org/ groups/professional_responsibility/publications/model_rules_of_professional_conduct/model_rules_of_p rofessional_conduct_table_of_contents.html $>$.

9 Chris Graham, 'How Sacked Attorney General Sally Yates Responded to Jeff Sessions When Asked If She Would Defy Donald Trump', The Telegraph (online), 31 January $2017<$ http://www.telegraph.co.uk/ news/2017/01/31/sally-yates-responded-jeff-sessions-asked-would-defy-president/>.

10 Quoted in David Luban, 'Introduction' in Deborah L Rhode and David J Luban (eds), Legal Ethics: Law Stories (Foundation Press, 2006) 1, 5. 
different ethical standards can be derived from deeper ethical fundaments. From this shared point of departure, it is possible to formulate employed professionals' ultimate moral requirements. In making this argument, this Part must confront the fact that professional ethics can be justified in several different ways, such as through common morality, role-requirements, social contract, and integrity. Rather than seeing this surfeit of philosophical approaches as a problem, we take the view that each perspective affords different (yet compatible) insights on professional ethics. In teasing out the prescriptions of five different approaches to professional ethics, we show how these different perspectives unite to press in a common direction. Part V explains and provides examples of this outcome, namely, that the professional ethic must be prioritised in application to the professional's signature ('constitutive') activities. Outside that domain, the ideal for executive decision-making would be to pursue a synthesis of the professional code and the organisation's own values and goals. Part VI considers some possible objections to this conclusion, before the final Part concludes.

\section{A Definitions and Terminology}

For our purposes, we will understand professions as those service industries with an occupational organisation (the 'professional organisation') that has laid down ethical and performance standards and (educational and experience-based) membership standards, based around the service providers' socially recognised expertise in a particular knowledge domain. The organisation possesses substantial powers to control entry into the profession on the basis of the membership standards, and at least some powers to ensure ongoing compliance with the ethical and performance standards. ${ }^{11}$ For expositional ease, we will typically speak as if the profession enjoys (something like) a legal monopoly on service provision, as has long been the case with archetypal professions such as medicine and law. ${ }^{12}$ However, different professions in fact vary considerably with respect to the legal protection of service monopoly they enjoy; for example, in some jurisdictions professional membership is not required to work as an engineer, but is required when employed in a supervisory role managing other engineers.

Even within the above-noted parameters constituting a profession, significant diversity may occur. In particular, the extent to which the professional organisation self-regulates (that is, actively polices compliance with its professional standards) can vary widely, with the state usually taking on a substantial regulative role. ${ }^{13}$ As well, specific professions can differ in various

11 This definition aligns with the conditions governments routinely employ to recognise professions. For example, Australia's Professional Standards Councils invoke the 'Five Es': Education, Ethics, Experience, Examination, Entity: Professional Standards Councils, Professional Standards Schemes $<$ http://www.psc.gov.au/professional-standards-schemes/are-you-ready-apply>.

12 Sociologists study the 'professional project' of industry groups striving to secure this monopoly on expertise and service provision. See Keith M Macdonald, The Sociology of the Professions (Sage Publications, first published 1995, 1999 ed) 8-13.

13 State regulatory input generally involves devolving powers of entry and exit to bodies that include lay government appointees. However, those bodies base their decisions on long standing professional norms. 
ways, one from another. While the forthcoming arguments aim to apply to most professions, the reader should be alert that idiosyncratic differences between professions (and even within jurisdictions) can impact on the conclusions drawn. ${ }^{14}$

The profession's ethical standards ('professional ethics') will include codes of ethics, which we will understand as an umbrella term including aspirational statements of values and overall goals (such as the public goods defining the professional activity). It will also include finer-grained 'codes of conduct' that lay down specific, enforceable 'black-letter' duties, as well as guidance both in method and substance for the greyer areas. ${ }^{15}$

We employ the term 'public service ethics' to connote the ethics of state actors like public servants, while 'corporate ethics' (incorporating 'Corporate Social Responsibility') will refer to the ethics of private enterprise, especially as pursued by large corporations. ${ }^{16}$ Like 'professional ethics', these two terms can cover aspirational values and goals to be pursued, and also fine-grained obligations.

Finally, it is important to distinguish ethical dilemmas from temptations. ${ }^{17}$ As Gunz and Gunz explain: 'Dilemmas are, by definition, difficult situations in which there is no obviously "right" course of action, typically pitting the dictates of the profession's ethical code against the interests of someone else - the client, the employer, or the professional herself' ${ }^{18}$ Resolving such tensions in the best possible way requires serious thought and often sophisticated judgment. This article's two research questions focus on dilemmas. Contrariwise, a temptation occurs when it is clear what the morally right answer is - but the agent nevertheless feels inclined to do the opposite, perhaps because of self-interest,

The loss of exclusive control by the professions is not so much seen as a denial of professional norms, but as a way of ensuring that they are upheld by representatives of those they claim to serve.

14 For example, the 'Contract Approach' noted in Part V(D) applies most strongly when professionals enjoy a monopoly on service, or other lucrative social goods for which their professional ethics can be seen as a quid pro quo. See Tetsuji Iseda, 'How Should We Foster the Professional Integrity of Engineers in Japan? A Pride-Based Approach' (2008) 14 Science and Engineering Ethics 165, 167, 175.

15 While we shall not interrogate the content of professional ethics requirements in any detail in this article, it bears mention that there can be significant contestation over the substance of these requirements. For example, even the (ostensibly straightforward) duty of lawyers to behave with fidelity to the law has been vigorously disputed. See William H Simon, 'Should Lawyers Obey the Law?' (1996) 38 William and Mary Law Review 217; David B Wilkins, 'In Defense of Law and Morality: Why Lawyers Should Have a Prima Facie Duty to Obey the Law' (1996) 38 William and Mary Law Review 269.

16 We employ the term 'corporate ethics', rather than 'business ethics', to draw attention to our focus on large organisations. While much of what follows will be relevant for small to medium business enterprises, sheer size can foment shifts away from standard professional practices, such as through the pursuit of economies of scale, the disaggregation of project tasks, and the creation of managerial roles like the department manager. See, eg, Bévort and Suddaby, above n 2.

17 See Charles Sampford and David Wood, 'The Future of Business Ethics? Legal Regulation, Ethical Standard Setting and Institutional Design' (1992) 1 Griffith Law Review 56.

18 Hugh P Gunz and Sally P Gunz, 'The Lawyer's Response to Organizational Professional Conflict: An Empirical Study of the Ethical Decision Making of In-House Counsel' (2002) 39 American Business Law Journal 241, 253. 
pressure or inducements from superiors, clients and colleagues, lack of courage, perceived exculpatory circumstances, and so on. ${ }^{19}$

Differentiating dilemmas from temptations can be challenging. Consider the above-noted case of the UK lawyer advising his government on the NATO intervention. If we take the view that the UK government should never have been entertaining the possibility of an intervention, then the lawyer faced only a temptation (though 'pressure' in this case may be a more apt term). ${ }^{20}$ But if we think that the NATO intervention in Kosovo prevented the Serbian forces from committing heinous war crimes - such as occurred in Srebrenica - then the case presents as a dilemma, with the lawyer forced to consider morally important government priorities on the one hand (preventing ethnic cleansing), and the lawyer's obligation not to misrepresent the law on the other.

\section{PROFESSIONAL ETHICS}

Well-known accounts of professional ethical codes include three key features. ${ }^{21}$

1. Duties to an acknowledged public good. These duties may be expressed in terms of duties to clients, members of the public, or vital social institutions (eg, lawyers' specific duties to the court) ${ }^{22}$ In all cases, it is the collectively delivered public good that provides the ultimate justification for a profession, its 'licence to operate', and the benefits and privileges that it receives from the community. The public goods' overriding social importance shapes other duties, so that pursuing the clients' interests is performed in a way that furthers the public good, rather than compromising it.

2. Duties to the client. These duties take the form of fiduciary responsibilities to make decisions and render judgments in the client's best interests, and without concern for other (eg, self-interested) agendas. Many of these duties (including confidentiality) respond to the manifold vulnerabilities of clients seeking professional services. ${ }^{23}$

19 While this article does not directly broach the question of separate institutional mechanisms for dealing with temptations, the clearer the ethic's nature and priority, the less scope employed professionals will have for allowing moral ambiguity to burnish self-interested actions (see Part VII).

20 The Goldstone Commission agreed that the NATO intervention was illegal - while coming to the jurisprudentially suspect conclusion that it was 'legitimate'. See Sampford, 'Legality and Legitimacy', above $\mathrm{n} 4$.

21 See, eg, Damian Grace and Stephen Cohen, Business Ethics (Oxford University Press, $5^{\text {th }}$ ed, 2013) 150; Charles Sampford, 'The Ethics of Employed Lawyers' in Charles Sampford and Hugh Breakey (eds), Law, Lawyering and Legal Education: Building an Ethical Profession in a Globalizing World (Routledge, 2016) 188, 189-91; Hugh Breakey, 'Supply and Demand in the Development of Professional Ethics' (2016) 15 Research in Ethical Issues in Organizations 1.

22 The profession's public good parallels its 'Public Institutional Justification': see below n 80 and accompanying text.

23 Breakey, 'Supply and Demand', above n 21, 7-8. 
3. Duties to the profession itself. These duties include obligations not to bring the professional community into disrepute, and various other duties that can enhance the profession's trustworthiness, perceived expertise, dignity and collegiality.

In all cases, the duty to the public good comes first, the client second, and the profession third. The individual professional's pursuit of their own interests can occur only within the confines set down by these three sets of obligations though those who perform their professional duties well are expected to earn a more than adequate income.

Importantly, professional ethics tend to be constitutive and positive rather than regulative. ${ }^{24}$ That is, rather than listing off an array of constraints on the agent's behaviour (a 'regulative' or 'negative' approach), the ethic puts forward a positive account of the activity or activities the professional is expected to perform (activities that 'constitute' the professional activity). Using accounting ethical codes as an example, ${ }^{25}$ Grace and Cohen explain how such codes:

exist to promote the practice of accounting, not to restrict practitioners or catch out frauds. The whole purpose of accounting is to give an accurate and reliable - or, according to the classic phrase, 'a true and fair' - account of a company's business affairs ... ${ }^{26}$

In what follows, we term the activity set down in the professional ethic as the profession's 'constitutive activity'. The 'constitutive activity' contains ethical values within its very description. Ceteris paribus at least, promoting health by medically curing a person is a good thing, as is promoting justice by defending a client's legal entitlements, educating and informing the public, and so on. Importantly, the constitutive activity will be framed in a way that allows it to contribute to larger social goods as well as benefiting individual clients. For example, the fidelity of accountants and auditors' work can play a vital 'gatekeeper' role in markets, allowing outsiders - including investors and government agencies - to form a credible and informed understanding of a corporation's financial position. ${ }^{27}$ Equally, defence attorneys can provide a spirited defence of their clients - but only in ways that, as part of a larger system of adversarial criminal justice, leads to desirable social outcomes. ${ }^{28}$ So too,

24 Grace and Cohen, above $\mathrm{n} 21,171-2$. The point can also be made in terms of professions performing a 'constituting task': Kenneth Kipnis, 'Ethics and the Professional Responsibility of Lawyers' (1991) 10 Journal of Business Ethics 569, 575. This echoes the distinction between positive and negative ethics and morality, set out in Charles Sampford, 'Law, Institutions and the Public/Private Divide' (1991) 20 Federal Law Review 185.

25 Accounting ethical codes are just one of many types of ethical codes that are constitutive and positive. A striking multi-layered constitutive ethic is set down in Australian Institute for Teaching and School Leadership, ‘Australian Professional Standards for Teachers' (February 2011). The Standards describe the constitutive activities and tasks of the teacher, and then lists four stages (graduate, proficient, highly accomplished, lead) and their required capabilities of performance.

26 Grace and Cohen, above $\mathrm{n} 21,171$.

27 On the importance of these gatekeeping roles, see John C Coffee, Jr, 'Understanding Enron: "It's About the Gatekeepers, Stupid”' (2002) 57 The Business Lawyer 1403; John C Coffee, Jr, 'What Went Wrong? An Initial Inquiry into the Causes of the 2008 Financial Crisis' (2009) 9 Journal of Corporate Law Studies 1.

28 Kipnis, above n 24. 
engineers' standards of safety allow the ordinary public to enjoy a blanket trust in the structural integrity of the buildings and bridges they use every day. ${ }^{29}$ The constitutive activity thus benefits individual users of professional services in a way that also promotes important large-scale public goods. ${ }^{30}$

With its prescribed positive duties for performing the constitutive activities, and other principles and constraints that serve the public good, professional ethics tend to focus on rules and practices (rather than on directly and flexibly pursuing socially desirable outcomes). In technical philosophical terms, the professional approach tends more to the deontological, while a flexible, goaloriented approach is more utilitarian. ${ }^{31}$

\section{ADDING A LARGE ORGANISATION AS EMPLOYER TO THE MIX}

An intuitive picture of the main elements of the professional's work environment might include: the professional as sole agent or in a small partnership; individual and corporate clients; the professional organisation; and the wider community as a collective or as specific third-party stakeholders.

As we saw in the foregoing Part, the professional will have duties to all the other elements in this group. Various situations will provide temptations for the dereliction of those duties. For example, the professional might breach duties to the client, perhaps by being influenced by monetary factors to distort their professional advice. A converse example might have the professional colluding with the client against public interest, such as with lawyers and clients conspiring to violate duties to the court, or an engineer signing off on unsafe work.

Adding a large organisation as employer to the mix refigures this traditional picture. Consider three different types of large organisations that routinely employ professionals: ${ }^{32}$

1. A collective of one type of professional, whose purpose is to perform their professional work (the 'constitutive activity') on a large or consolidated scale:

29 Michael Davis, 'Thinking Like an Engineer: The Place of a Code of Ethics in the Practice of a Profession' (1991) 20 Philosophy \& Public Affairs 150.

30 See Part V(B) below.

31 Several authors stress the deontological nature of much professional ethics, which is implicit in the idea of professionals having a constitutive activity or constituting task. See Grace and Cohen, above n 21, 171-2; Kipnis, above n 24, 575; Kenneth L Carper, 'Engineering Code of Ethics: Beneficial Restraint on Consequential Morality' (1991) 117 Journal of Professional Issues in Engineering Education and Practice 250, 254-5. Professional ethics' deontological flavor also arises in studies contrasting ethical climates: see below n 48 .

32 Some large organisations smear these neat categorisations. Consider, for example, the public hospital, which retains elements of each of the three sorts. Consider also banks, which as well as employing different professionals (lawyers and accountants), are also populated by bankers and financial advisers who themselves can have professional aspirations, and whose work contains quasi-professional elements: Justin O'Brien et al, 'Professional Standards and the Social Licence to Operate: A Panacea for Finance or an Exercise in Symbolism?' (2015) 9 Law and Financial Markets Review 283. 
o The corporatised professional firm in, eg, accounting, law or auditing (including the multi-professional firm);

o Organisations that create a consolidated good or service constructed from the combination of individual professional work: eg, newspaper (journalists), church (clergy), school (teachers).

2. A corporation employing salaried professionals, that produces or provides some other (non-professional) market good or service:

o For example, a mining firm employing salaried ('in-house') lawyers, accountants and engineers.

3. Public sector:

o For example, the many services of lawyers called upon in government and public service. ${ }^{33}$

These different types of large organisational employer can facilitate different sorts of ethical dilemmas and temptations, and present different opportunities for, and limitations to, crafting responses to those challenges. ${ }^{34}$ In particular, adding a large organisation to the professional landscape may foster new types of ethical breaches through new types of collusive relationships. For example, the employer might pressure the professional to reduce standards in order to meet productivity targets - weakening their duties to clients or to third-party stakeholders. When the large employing organisation is also the client (eg, in-house lawyers in large corporations), this reduces the risks of vulnerable clients being exploited, but magnifies the risk of the professional and client/employer colluding against the public good..$^{35}$

As well as creating new opportunities for temptations to breach ethical duties, large employing organisations have their own ethical responsibilities and legitimate goals. When these conflict with professional responsibilities, the threat arises of ethical dilemmas, where employed professionals are torn between holding firm to their standard professional ethics, and prioritising the duties they owe to their employers.

33 See Sampford, 'The Ethics of Employed Lawyers', above n 21, 196-8.

34 The different organisations can also have power divided and distributed within them in different ways; an issue that may itself engender ethical concerns. Hutton and Massey consider whether a professional (engineer) employed by the state owes their responsibility to the direct employer (a board of administration) or to the ultimate employer (the electorate): William L Hutton and Andrew Massey, 'Professional Ethics and Public Service: Can Professionals Serve Two Masters?' (2006) 26 Public Money \& Management 23, 29-30. Similar issues arise in private enterprise, especially for lawyers: see Christine Parker et al, 'The Ethical Infrastructure of Legal Practice in Larger Law Firms: Values, Policy and Behaviour' (2008) 31 University of New South Wales Law Journal 158, 162-3; Rosen, 'Serving the Organizational Client', above $\mathrm{n} 7$.

35 For example, as occurred with the government lawyers in the Kosovo case. See above nn 4-6 and accompanying text. Parker et al explore the ways that the structure of large law firms impact on the above-noted types of ethical failure: Parker et al, above n 34, 161-72. 


\section{ETHICAL DIFFERENCES AND POSSIBLE RESPONSES}

This Part argues that the prospect of genuine ethical dilemmas for employed professionals is a real one. While there are many areas of overlap and synergy between professional, corporate and public sector ethics, the obligations and values prioritised by professional ethics can differ from other ethical standards. Once this has been shown, we move to considering three different modes of responding to the resulting ethical dilemmas: responses of aggregation, prioritisation and synthesis.

\section{A Substantive Differences}

The differences between professional ethics (on the one hand) and corporate and public service ethics (on the other) may arise at the level of the ethics' overall thematic nature, at the level of specific obligations, or at the level of the values prioritised by ethical actors in each case. We consider each in turn.

\section{$1 \quad$ Large-Scale Thematic Differences}

We have already seen that professional ethics tend to be phrased in positive and deontological terms, with an ethically-infused constitutive activity laid down as the exemplary practice of the professional. The constitutive activity will centre on providing expert advice or service to a client in such a way that furthers the public good.

Corporate and public service ethics differ. Corporate ethics are flexible and dynamic, and responsive to multiple stakeholders, including shareholders, employees, environmental impacts, community stakeholders, and even tax contributions to the public purse. ${ }^{36}$ Even as they deal with myriad ethical concerns, corporate ethics principles apply to more open-ended roles. Managers, for example, are given specific goals but are expected to be adaptable and innovative, responsive to a variety of different factors, and able to integrate those demands together to create good outcomes. ${ }^{37}$ Because of this, the specific activities that their role requires can differ substantially from one moment to the next. ${ }^{38}$ Managers thus require the freedom allowed by an ethic of negative duties ('thou shalt nots'), and a positive but generalised concern for various stakeholders, that together empower them with an open-ended flexibility to pursue the organisation's goals. ${ }^{39}$ Qualitatively, the nature of the applicable ethic

36 Thomas Maak, 'Undivided Corporate Responsibility: Towards a Theory of Corporate Integrity' (2008) 82 Journal of Business Ethics 353; John Christensen and Richard Murphy, 'The Social Irresponsibility of Corporate Tax Avoidance: Taking CSR to the Bottom Line' (2004) 47(3) Development 37; Grace and Cohen, above $\mathrm{n} 21$.

37 Richard Barker, 'The Big Idea: No, Management is Not a Profession' (2010) 88 Harvard Business Review 52.

38 That said, it is still possible to shift management in a more professional direction, in particular by determining the role's responsibilities in line with the delivery of benefits to the community that provides the basis for the company's 'social licence to operate': see below Part V(D) 'The Contract Approach'.

39 There are analogies here to the public service. See Charles Sampford, 'Institutionalising Public Sector Ethics' in Noel Preston (ed), Ethics for the Public Sector: Education and Training (Federation Press, 1994) 14. 
is thus likely to differ from the more tightly focused codes and constitutive activities set down by the professional ethic.

The public service ethic shares the profession's concern with the public good. However, public servants can work directly, deliberately and flexibly (consistent with their enabling legislation and regulation) as they pursue this goal. They are not confined to a deontological ethic, pursuing a specific, constitutive activity in the manner of the professional. ${ }^{40}$ So too, public servants can answer to a wide array of stakeholders, and often need to respond innovatively and adaptably to their needs.

\section{Different Obligations}

In terms of specific obligations, professional ethics can conflict with the dictates of common morality - understood as the common-sense morality governing people generally. ${ }^{41}$ To take the example of law, a lawyer must observe confidentiality even in cases where the public would benefit from knowing certain matters of fact, and to robustly defend the interests of the accused, using the full resources of the law to the best of their ability, even if the lawyer believes the defendant is guilty. Both of these obligations prima facie violate duties that stem from common morality. ${ }^{42}$ Insofar as these duties bind both corporate and public actors (such duties are common, after all), this creates a tension with the privileges of professionals to eschew such duties in the pursuit of their professional task.

Grace and Cohen provide a specific example of the different moral expectations applying to business and professions, considering a case where a customer asks advice of a car salesman and a patient asks advice of a doctor. ${ }^{43}$ In the former case, the salesman is entitled to limit his recommendations to the cars he is offering for sale. The customer will not expect him to say that - in order to fulfil the customer's desires - it would be best to head to his competitor across the road. With the doctor, on the other hand, the patient will expect that the treatment prescribed is the best medical option, all things considered. For the doctor to prescribe medication on the basis of a kickback from the drug company, for example, constitutes a clear breach of professional obligations. This situation illustrates a difference between what the professional must do, and what the salesperson can do. However, a genuine tension between conflicting obligations arises if the car salesman possessed a duty to his employer that he direct customers' attentions exclusively to the wares he has for sale. Such a duty would

40 This difference is suggested in the results of the research project on public sector values discussed in Grace and Cohen, above n 21, 176-9.

41 See, eg, the cases noted in David K McGraw, 'A Social Contract Theory Critique of Professional Codes of Ethics' (2004) 2 Journal of Information, Communication and Ethics in Society 235; Rosamond Rhodes, 'Understanding the Trusted Doctor and Constructing a Theory of Bioethics' (2001) 22 Theoretical Medicine 493. Potential clashes between professional and corporate ethics will increase if we have particularly demanding corporate ethics, whose objectives might clash with the professional's specific concern with the client's interests: on demanding corporate ethics, see, eg, the many dimensions of ethical obligation described (under the banner of 'corporate integrity') in Maak, above n 36, 358-60.

42 See Kipnis, above n 24, 569.

43 Grace and Cohen, above n 21, 149-50. 
not be surprising: company employees clearly possess contractual obligations to their employer, and company executives clearly have duties to their stockholders - such as to work towards the corporation's profitability. ${ }^{44}$

Potential differences in obligations between professionals and public servants surface when public sector managers are quizzed about inherent difficulties and obstacles to ethical performance: managers highlight differences between professional and public sector values, and in particular the professionals' lack of engagement with organisational goals and purposes. ${ }^{45}$ Part I's sketch of professional ethics bears this out. While professionals possess duties to the public interest, these are specified in terms of providing a discrete service in such a way that its competent fulfilment will - when practiced collectively and as part of an overall institutional regime - benefit the public by delivering an acknowledged public good. But this modus operandi differs from an open-ended and explicit commitment to improve the public in any ways that might fall into a particular public sector organisation's ambit, like health or education. In this way, the public service obligation to directly benefit the public through discrete policy achievements can clash with the professional obligation to indirectly benefit the public through playing a lynchpin role in larger institutional processes.

There are thus several prima facie tensions between the distinct obligations required by corporate ethics, public service ethics, and common morality on the one hand, and professional ethics on the other.

\section{Different Values and Virtues}

If we follow Milton Rokeach in understanding values as enduring, singular, prescriptive beliefs about the personal or social desirability of acts or goals, ${ }^{46}$ then we can discern different values - or at least a different prioritisation of values - between professional ethics, as contrasted with both corporate ethics and public service ethics. Professional ethics typically foreground values of confidentiality, fiduciary obligations to clients, independence, autonomy, and collegiality. These values can clash with those of private enterprise, which are more likely to foreground profitability (including economic cost-benefit decision-making), efficiency, competitiveness and innovation. These differences in values appear sharply in studies of 'institutional logics', 'identity scripts' and 'organisational-professional conflict', where organisation members must navigate between professional archetypes and corporate-bureaucratic logics, values and methods. ${ }^{47}$ The differences also surface in studies of 'ethical

44 The extreme version of this view comes from Milton Friedman, 'The Social Responsibility of Business Is to Increase Its Profits', New York Times (New York City), 13 September 1970. We critique this extreme view in Part VII(C) below.

45 Grace and Cohen, above n 21, 178.

46 Serving as imperatives for action as well as standards for judging actions, Rokeach-ean values are always 'centrally connected' to other beliefs and attitudes. See Milton Rokeach, Beliefs, Attitudes and Values: A Theory of Organization and Change (Jossey-Bass Publishers, 1976) 123-4, 159-60.

47 See Bévort and Suddaby, above n 2, where the authors speak of 'competing' and even 'contradictory' logics, and explore the different values (between professional and managerial logics) inherent in mandated practices, workplace design, scripts (eg, team meetings), and even props and rituals. In the context of the legal profession, Gunz and Gunz's research provides evidence that many in-house counsel 
climates'. In ethical climate theory, professionals' values are found to centre on deontological, rule-based principles, and it is such 'principled' ethical climates that cultivate professionals' commitment to their organisation. ${ }^{48}$ In contrast, business and corporate values are more likely to fit a more goal-directed or utilitarian ethical climate. ${ }^{49}$

With respect to public service ethics and professional ethics, the differences are not as sharp. ${ }^{50}$ In some cases, there is considerable overlap. For example, confidentiality and independence are important elements of the public servants' duties to give frank and fearless advice. Even so, differences do arise, for example, in the public servants' direct concern for the public good, and on their explicit prioritisation of lawfulness and accountability.

These different values parallel the different institutional logics typically used by employers. Bureaucratic and managerial control practices (emblematic of both corporations and public services) have long been seen to cut against the grain of professionals' autonomy and their internalised ethical standards..$^{51}$

Figure 1 sketches - in an illustrative form ${ }^{52}$ - the differentially prioritised values in private, professional and public service roles. Values in the centre area - such as honesty and reliability - tend to be prized on all sides, while values closer to each corner imply a greater prioritisation by that group.

shift their behaviour from that associated with the independent lawyer: Gunz and Gunz, above n 18, 27880. For some lawyers, this is a change in method rather than values; Gunz and Gunz's 'Advisor' still pursues outcomes consistent with their professional ethical demands, though this pursuit is performed in an organisation-centred way. However, the 'Technician' and the 'Observer' roles tended to downplay their professional responsibilities.

48 John B Cullen, K Praveen Parboteeah and Bart Victor, 'The Effects of Ethical Climates on Organizational Commitment: A Two-Study Analysis' (2003) 46 Journal of Business Ethics 127; William E Shafer, 'Ethical Climate, Organizational-Professional Conflict and Organizational Commitment: A Study of Chinese Auditors' (2009) 22 Accounting, Auditing \& Accountability Journal 1087. For an overview and meta-analysis of ethical climate theory, see Kelly D Martin and John B Cullen, 'Continuities and Extensions of Ethical Climate Theory: A Meta-Analytic Review' (2006) 69 Journal of Business Ethics 175.

49 In ethical climate theory, these are the distinct 'egoistic' and 'benevolent' climates: see Cullen, Praveen Parboteeah and Victor, above $\mathrm{n} 48$.

50 On the differences between public service values and business values, see Leo Huberts, The Integrity of Governance: What It Is, What We Know, What Is Done and Where to Go (Palgrave Macmillan, 2014) 95.

51 See the literature cited in Shafer, above n 48, 1087-88; Bévort and Suddaby, above n 2.

52 Figure 1's positioning of the professional values in particular is purely illustrative, and intended only to provide a flavour of different priorities, rather than any sort of quantitative measurement. The membership and positioning of the values on the Private-Public (left-hand) axis derive qualitatively from the studies outlined in Huberts, above n 50, 94-7. The values for professions are taken from existing codes and the moral-philosophic literature on professions. Their placement on the Private-Professional (bottom) axis was informed by Bévort and Suddaby, above $\mathrm{n}$ 2, and, on the Public-Professional axis, by Grace and Cohen, above n 21, 176-9. 


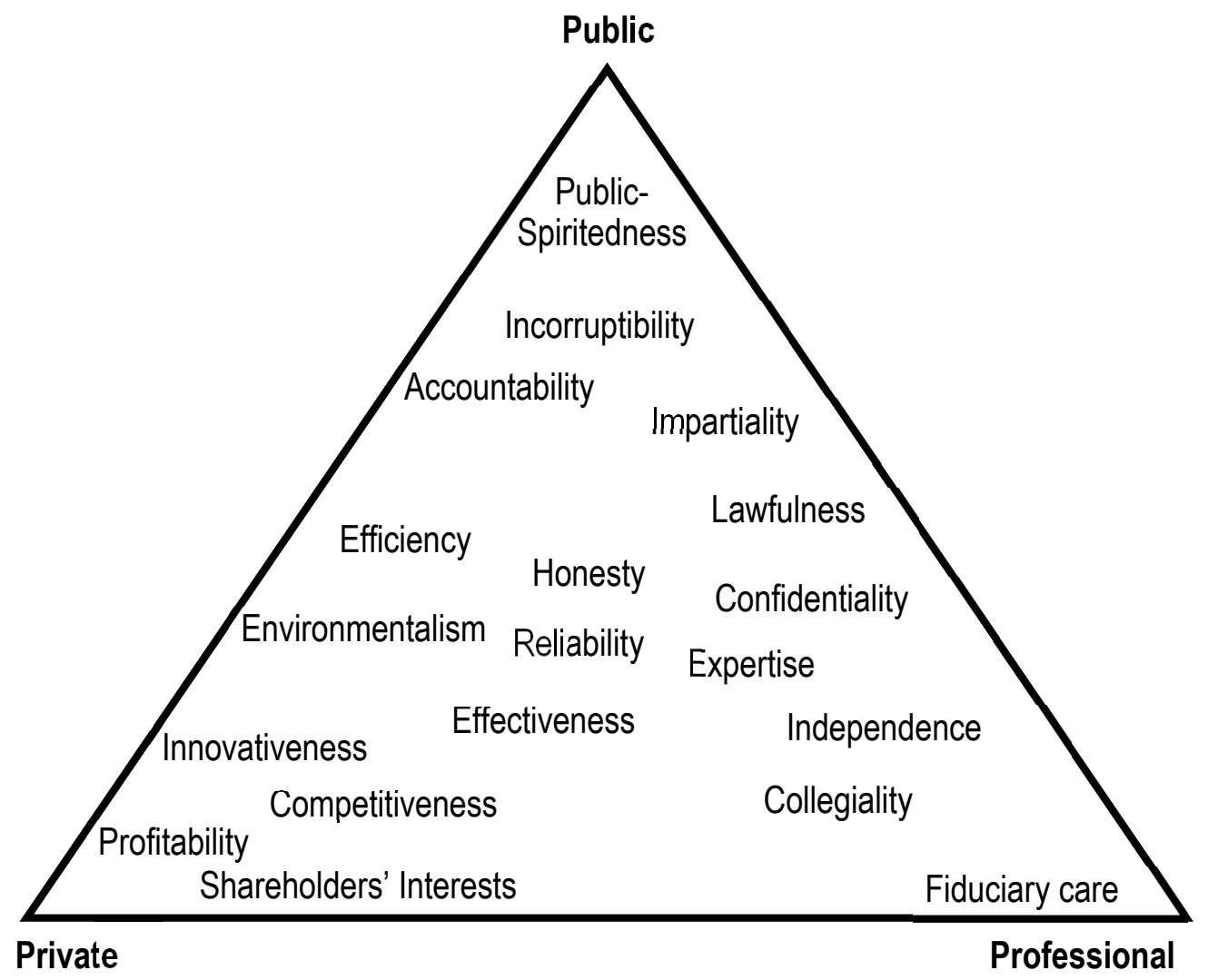

Figure 1: Occupational Values: Public, Private and Professional

Of course, these different weightings only imply generalised differences in relative prioritisation. Value differences between professional and nonprofessional 'casts of mind' can be overemphasised, especially with respect to whether such differences 'travel' to different employment positions. For example, Rosen, Parker and Nielsen examine cases where compliance officers have professional versus non-professional backgrounds. They find only limited differences in the company's resulting risk perceptions, compliance structures and substantive outcomes..$^{53}$ Furthermore, all of Figure 1's values can of course be present in any given occupation role: it is not difficult to think of examples of public-spirited professionals, innovative public servants, and business owners who treat their customers with an almost fiduciary care. ${ }^{54}$ Indeed, sometimes ethical codes will explicitly enshrine diverse values - such as public service

53 Robert Eli Rosen, Christine E Parker and Vibeke Lehmann Nielsen, 'The Framing Effects of Professionalism: Is There a Lawyer Cast of Mind? Lessons from Compliance Programs' (2012) 40 Fordham Urban Law Journal 297.

54 Collegiality is important in all workplaces, especially in emphasising a common mission. Innovation in policy and cost effectiveness in delivery are increasingly given greater importance in the public service. Profits delivered in government enterprises are encouraged and recognised as a means for funding other goals either within the government enterprise (eg, capital investment and helping poorer consumers) or more generally for funding welfare. 
codes explicitly highlighting innovativeness ${ }^{55}$ - illustrating that we are dealing with a complex and dynamic continuum, rather than a neat trichotomy.

Summing up, as well as differences in overall thematic nature and in specific obligations, there are also differences in terms of the values foregrounded by each ethic.

\section{B Three Possible Responses to Differing Ethical Demands}

When faced with substantive differences between obligations - whether at the level of broad values or specific obligations - moral agents possess several avenues to resolve the challenge.

\section{Simple Aggregation}

One way of resolving potential tensions is to simply add the two codes together, piling the duties of professional ethics onto the duties of corporate or public sector ethics, without losing a single member of either set of obligations. This approach would be possible if each ethical code involved a series of discrete action-constraints: 'thou shalt nots' that proscribe certain types of actions ('negative duties'). In such a situation, any two sets of ethical codes can be reconciled by obeying both sets of restrictions. For example, the 'do nots' of professional ethics will trump any 'dos' of corporate ethics and (though perhaps more rarely) the 'do nots' of corporate ethics will trump the 'dos' of professional ethics.

However, simple aggregation does not work well when either of the codes puts forward positive duties, requiring agents to perform particular acts or achieve particular results. We have already seen that all three types of ethics imply positive duties (for professionals to perform their constitutive activities, for public servants to work towards the public good, and for business to be proactively responsive to a wide range of stakeholders, not least owners and shareholders). Once an agent is faced with two different activities that must be positively performed, or two different goals that must be pursued, then a simple moral addition cannot resolve the issue. ${ }^{56}$

55 Moataz Fattah's analysis of public officials' codes of ethics highlights many of the quintessential public service values, such as concern for the public interest, fairness and impartiality, and accountability. However, some city codes explicitly include elements like innovation, more associated with private enterprise: see Moataz Fattah, 'Professional Ethics and Public Administration in the United States' (2011) 34 International Journal of Public Administration 65, 70.

56 A further problem is that certain types of privileges (in the technical Hohfeldian sense of 'no-duties') enable the professional to perform their positive duties (such privileges can be termed 'mandatory rights'). In these circumstances, adding up the 'constraints' of each ethic is unworkable, because some of those constraints will overwhelm the privileges required to perform the professional work. On privileges in this sense, see Wesley Newcomb Hohfeld, 'Some Fundamental Legal Conceptions as Applied in Judicial Reasoning' (1913) 23 Yale Law Journal 16. On mandatory rights, see A John Simmons, The Lockean Theory of Rights (Princeton University Press, 1992). 


\section{Prioritisation (Supremacy)}

A second response allows one ethics' demands to trump the others' demands in any cases of conflict. In philosophical terms, this would allow one ethic to 'lexically dominate' the other: the primary ethical code's obligations are resolved in full, and only after its obligations are exhausted does the agent begin considering the next layer of obligations. For example, the obligations of the professional code of conduct could lexically dominate the specific obligations of corporate or public service ethics.

This prioritisation could be context-specific, applying to only certain types of decisions, actions or circumstances (in what follows, we will recommend one version of this contextualised prioritisation). For example, professional ethics could dominate in all direct interactions with clients, but the organisation's ethics might enjoy priority outside this specific context.

\section{Synthesis}

A final possibility lies in drawing the main themes and concerns of the two ethical codes together to craft a new complex of broad values and specific obligations. This synthesis might involve prioritising certain obligations at certain times, but perhaps mitigating their demands by reference to other responsibilities. Equally, it might require developing new types of duties that aim to synergise the hitherto conflicting codes. The newly fashioned ethic might deliver straightforward obligations, or it may call for sophisticated and contextual judgment ('practical wisdom', as Aristotle would call it) by role-holders as they navigate their way through potential conflicts on a case-by-case basis. ${ }^{57}$

\section{FIVE APPROACHES TO PROFESSIONAL ETHICS}

We have seen that professional ethics can require different obligations and values from the ethics of the large organisational employer (whether private or public). We then noted three possible responses to these differences: simple aggregation; prioritisation; and synthesis. But which avenue should we use, and when?

In order to answer these questions, this Part looks to the deeper ethical bedrock that justifies and explains the different sets of duties. Specifically, we consider five different approaches to professional ethics. ${ }^{58} \mathrm{We}$ then turn to consider what those theories would require of corporate ethics, and what they would then say about the employed professional's duties. For ease of exposition, our focus here will be on professionals employed by large organisations in the

57 Professionals themselves would not be unfamiliar with having to negotiate challenging tensions in their ethical responsibilities. Many ordinary professional codes put forward duties towards the public interest, the client and the profession, and clashes between these disparate obligations are not uncommon.

58 Each 'approach' encompasses a variety of different theories (for example, there are many different ways of theorising the 'quid pro quo' that is the hallmark of the 'Contract' approach). These theories may disagree on many particulars, but they share an overall approach towards justifying and delineating professional obligations. 
private sector. Much of what we say here will be relevant to resolving the ethical demands of professionals employed in the public sector (to which we will return in Part VI).

In a nutshell, we argue that the five main approaches to professional ethics, when applied to large corporate employers, will all press in the same direction: namely, towards the prioritisation of the professional ethic in the constitutive activity, and the synthesis of the two ethical codes in areas outside that activity. We contend that on each of the approaches discussed, the same types of morally relevant considerations that required the professional role-obligations remain for the employed professional, thus requiring the prioritisation and synthesis of professional ethics.

One way of understanding the ensuing argument would be to take a disjunctive view that one (and only one) of the following approaches to professional ethics is correct. However, while each approach can stand on its own merits, they are each in principle compatible, and many influential (and commonsense) accounts of professional ethics will appeal to them all. Consider David Wilkins' measured discussion of lawyers' special duties to respect the law. Wilkins begins by observing that common morality must stand as the ultimate judge of particular role-related actions as well as of the lawyer's role itself. But he immediately adds:

Lawyers are more than ordinary citizens; they have been given a monopoly by the state to occupy a position of trust both with respect to the interests of their clients and the public purposes of the legal framework. As a result, the kind of deliberation that may be appropriate in the realm of personal moral decision making will not always produce the social goods that society legitimately expects from a regime of professional ethics. ${ }^{59}$

In the terms employed here, after nodding to 'common morality', Wilkins draws from the 'social licence to operate' and 'role-requirements' approaches. Before his analysis is complete, Wilkins includes both tradition and integrity ('oaths') - thus covering all five approaches to professional ethics. ${ }^{60}$ In line with Wilkins' argument, we suggest that each of the following approaches to professional ethics is premised on a sensible insight about the nature of moral obligation. ${ }^{61}$ The fact that all five (different but compatible) insights press in the same direction thus provides a multifaceted case for accepting the conclusions. ${ }^{62}$

While the following five arguments aim to mount a concerted philosophical case for the continuing moral significance of 'traditional' professional values, it is worth highlighting that empirical research shows the ongoing relevance of

59 Wilkins, above n 15, 274.

60 Wilkins, above n 15, 275, 289-90. Wilkin's major justification hones in on the social licence to operate: at $291-2$.

61 On drawing insights from different (and ostensibly opposing) philosophical perspectives, see Charles Sampford, 'Law, Ethics and Institutional Reform: Finding Philosophy, Displacing Ideology' (1994) 3 Griffith Law Review 1; Breakey, 'Supply and Demand', above n 21.

62 The occurrence of different ethical approaches resulting in similar moral prescriptions is not an uncommon result in moral philosophy. Utilitarianism, virtue theory, contract theory and deontology all accord in vindicating the standard duties of common morality (honesty, non-harm, beneficence, etc). 
these values for actual professional's practical work. ${ }^{63}$ Aspiring professionals themselves acknowledge the relevance of these values as they work to build their professional identities. For example, Holmes et al found that new legal practitioners take seriously not only their duties to clients, but also the importance of collegiality and the public service orientation, and that they work to craft a 'comfortable convergence' between their own values with those modelled by their colleagues. ${ }^{64}$ The following philosophical exploration can thus hope to attach to existing needs, values and reflections of contemporary professionals themselves.

\section{A The 'Common Morality' Approach}

\section{Application to Professional Ethics}

Some philosophical theories understand professional ethics to derive from ordinary, common-sense moral obligations, as they apply to the specific circumstances - the 'fact situations' - of professionals. ${ }^{65}$ Beauchamp and Childress' work is one of the most well-known of such theories, developed in the context of medical ethics. In their Principles of Biomedical Ethics, they defend four key moral principles (hence the descriptive term 'principlism') that underwrite general morality, and professional ethics in particular: respect for autonomy; non-maleficence; beneficence; and justice.

These principles aim to be intuitive, drawn from the everyday ('common') morality that myriad cultures and humans use to guide their ethical life. ${ }^{66}$ The principlist approach to bioethics applies these principles to the specific fact situation of medical practitioners, in order to derive and justify their specific professional responsibilities. For example, respect for autonomy requires that doctors allow final choices on treatment to be made by their (competent) patients,

63 See, eg, Neil Hamilton and Verna Monson, 'The Positive Empirical Relationship of Professionalism to Effectiveness in the Practice of Law' (2011) 24 Georgetown Journal of Legal Ethics 137. The applicability of such professionalism to not only law but also medicine, engineering, and nursing, is outlined in Neil Hamilton and Verna Monson, 'Legal Education's Ethical Challenge: Empirical Research on How Most Effectively to Foster Each Student's Professional Formation (Professionalism)' (2012) 9 University of St Thomas Law Journal 325, 327-31.

64 Vivien Holmes et al, 'Practising Professionalism: Observations from an Empirical Study of New Australian Lawyers' (2012) 15 Legal Ethics 29, 49. See also, in the context of nursing: Brighid Kelly, 'Preserving Moral Integrity: A Follow-Up Study with New Graduate Nurses' (1998) 28 Journal of Advanced Nursing 1134.

65 Naturally, philosophical controversy surrounds the ultimate substance and justification of the principles of common morality. However, many see sufficient convergence on basic principles to justify this general methodology of deriving the duties of professional ethics from the contextualised application of basic moral principles. Still, some critics argue that key features of professional ethics cannot be derived from the common morality, suggesting the need to incorporate other approaches: see Alan Tapper and Stephan Millett, 'Is Professional Ethics Grounded in General Ethical Principles?' (2014) 3(1) Theoretical and Applied Ethics 61; Kipnis, above n 24.

66 Tom L Beauchamp and James F Childress, Principles of Biomedical Ethics (Oxford University Press, $6^{\text {th }}$ ed, 2009); Hugh Breakey, 'Moral Pluralist Theories' in Peter Bowden (ed), Applied Ethics: Strengthening Ethical Practices (Tilde University Press, 2012) 17. For a similarly pluralistic approach (that is, a moral approach made up of a variety of irreducible principles, including consequential and deontological elements) applied to engineering ethics, see Carper, above n 31. 
and also requires that doctors positively provide patients with the information that would allow them to make an informed decision. ${ }^{67}$

This ethical method allows for professionals to have special duties not required of other occupations. Whilst all occupations must observe the four principles (as they are ex hypothesi principles of common morality), the special fact situation of professionals - in dealing with the manifold vulnerabilities of their clients and patients - will require special types of responsibilities, such as duties of fiduciary care and confidentiality. Common morality duties of honesty and trustworthiness also give rise to many professional obligations ${ }^{68}$ such as accountants' obligations to provide an accurate report of an organisation's financial situation.

\section{Application to Corporate Ethics and Employed Professionals}

What then would this ethical approach require for employed professionals in the private sector? In principle, there should be no clash between different prescriptions, as business practitioners and professionals must both employ the same four moral principles, with each acknowledging their relevance to the specific fact situations each faces. When the fact situations overlap and combine, this will lead to elements of the prioritisation and synthesis methods noted above. Prioritisation of the professional code will be necessary because the multifaceted vulnerabilities faced by professional's clients will remain in the new setting, meaning that the professional responsibilities to clients (based on the principles of autonomy, non-malfeasance, and beneficence) will take precedence in any dealings with them. Outside of situations where these vulnerabilities are at stake (in particular, when well-resourced employing organisations replace vulnerable subjects as the professional's clients), synthesis may occur, as the four principles apply to the merged fact-situations.

\section{B The 'Role-Requirements' Approach}

\section{Application to Professional Ethics}

A second approach considers the 'macro' level of ethically desirable social institutions. This approach begins by establishing the legitimacy of a particular social institution. For example, an adversarial criminal law justice system might be defended as a reasonable way of fulfilling the vital social goals of deterring harmful conduct and obviating personal attempts at retribution. ${ }^{69}$ These goals may be pursued for utilitarian reasons, where the institution is deemed vital in maximising the overall level of happiness within the society. But many other sorts of political theories could be used to justify such institutions. ${ }^{70}$

67 Beauchamp and Childress, above n 66, 99-139.

68 In the context of medicine, see Rhodes, above $\mathrm{n} 41$.

69 See, eg, Kipnis, above n 24.

70 Kipnis specifically draws on John Locke, Two Treatises of Government (Hafner, first published 1690, 1947 ed). However, he resists hitching this position to any specific political theory, and rightly highlights that we may be 'considerably more confident that the social institution of adjudication is legitimate than we are about which foundational ethical theory is to the correct one to appeal to in demonstrating that legitimacy': Kipnis, above n 24, 572. For a similar approach that also leaves open the ultimate 
Once the institution's legitimacy has been established, the specific roles that institutional members will need to play for the institution to achieve its larger purpose must be delineated. This is where the ethical duties of professionals arise, as different role-holders will need to possess distinct sets of permissions, powers and obligations in order to reliably play their part in the larger task. ${ }^{71}$ Keeping with the above example, lawyers in an adversarial criminal justice system will need to perform certain sorts of activities for the larger regime to fulfil its function. Kipnis identifies two required roles as those of 'legal counselling' (to convey to clients what the law requires and permits) and of 'legal representation' (to provide clients with the protections the law entitles them). ${ }^{72}$ He then shows how these activities require certain sorts of duties: legal counselling requires confidentiality in order to empower clients to fully explain their situation, while representation in an adversarial system requires spirited advocacy (within bounds) to ensure the trier of fact hears competent competitive alternative cases under the rules of evidence.

This approach employs a device we shall see again in several other approaches canvassed below: the professional ethic allows the collective attainment of important large-scale social goals. By considering the rolerequirements of legitimate social institutions, we can see how professionals' responsibilities interlock with each other, and with other elements of key institutions, in order to collectively fulfil important social tasks.

\section{Application to Corporate Ethics and Employed Professionals}

This line of justification can be extended to corporate ethics. On this footing, certain sorts of privileges and powers are granted to businesses so the society can capture the overall benefits that markets deliver. For example, suppose utilitarianism was used to justify an adversarial justice system, and thereby articulate the codes of professional lawyers. We could then employ that same moral theory to consider the potential of markets, businesses and international corporations to contribute to overall human happiness. Presuming that (some form of) market-based economies would be justified on this basis, we would then work out the specific privileges (such as limited liability), powers (such as legal contract) and duties (such as respecting employee working conditions and contributions to the tax base), that role-holders within the market need to possess, for the market to secure the desired social benefits.

When institutions are created that share elements of both the market and the profession - as occurs with the employed corporate professional - we can expect

justification of the institution's legitimacy, see John Rawls, ‘Two Concepts of Rules' (1955) 64 Philosophical Review 3, 25-9. For application to ethics and institutions, drawing on Lon Fuller's similar idea of fulfilling key social functions, see Daniel E Wueste, We Need to Talk ... About Institutional Integrity (RIT Press, 2005).

71 Ethical duties, on this approach, can arise in two ways. First, some duties will be directly required for the professional to fulfil their role within the system. Second, in order to play their role, professionals will be granted certain privileges: see the 'mandatory rights' in above n 56. These 'privileges' may themselves create new risks of socially undesirable outcomes, and further duties may be required to protect against the professional's wrongful exploitation of those privileges. 
either a prioritisation (in favour of the one that is most vital in terms of its functional utility) or a synthesis of the two ethical codes. Whilst we cannot attempt a full application here, two points should suffice to prioritise the professional ethic at least in the confines of the constitutive activity.

First, the larger social institution housing the professional often boasts an overriding social importance. Indeed, for at least some professions - such as law and accounting - the integrity of their practice itself performs a vital role within the market, meaning that the more the market is deemed important, the more emphatically the community will prioritise the professional ethics that provide the legal and informational superstructure for that market. ${ }^{73}$

Second, many of the professional ethic's benefits are created collectively, based on the expectation that (almost) all professionals will (almost) always behave in this way. This normative consistency creates the balance within the adversarial criminal justice system noted above. Equally, it creates the objectivity and reliability of the work of actuaries and accountants, and people's trust in the expertise of teachers and doctors. ${ }^{74}$ These beneficial expectations of trust and reliability cannot be guaranteed if professionals may justifiably slough off their professional duties to pursue corporate goals. Since its very beginning, utilitarianism has concerned itself with the importance of overall types of actions that, when performed collectively, serve to establish beneficial expectations. ${ }^{75}$ Thus, the utilitarian will not only be concerned to respond beneficently to a client's vulnerability (the same duty we noted above under common morality), but also to establish a valuable social expectation that such vulnerabilities will always be respected by the professional. ${ }^{76}$

Both these points imply that the role-requirements of employed professionals must be prioritised, insofar as they are performing the constitutive professional activities.

\section{The Integrity Approach}

\section{Application to Professional Ethics}

On the integrity approach, the core of professional ethics lies in the profession reflecting on its work, asking questions about its values, and how those values can be furthered. This process can occur for individuals; it involves asking hard questions about one's values, giving honest and public answers, and trying to live by those answers. A person who does so has integrity, in the sense

73 Professionals like lawyers, accountants and auditors can provide vital 'gatekeeping' services that improve market outcomes and ward off systemic risks: Coffee, 'Understanding Enron', above n 27; Coffee, 'What Went Wrong?', above n 27.

74 Rhodes, above $\mathrm{n} 41$.

75 Jeremy Bentham's utilitarian defence of law and property rights employs this device: Jeremy Bentham, An Introduction to the Principles of Morals and Legislation (Batoche Books, 1781).

76 The situation might be different if upholding the professional duties seriously infracted upon beneficial market outcomes, in which case the utilitarian response may be more ambivalent. Arguably, this occurred in the specific context of professional restraints on advertising and publicising costs, which offered less benefit to clients and third-parties, and more directly clashed with some of the benefits of competitive markets: see McGraw, above n 41, 238-42. 
that they are true to their values. However, much of human life is lived in and through groups and institutions (including public agencies, corporations and professions). The integrity approach to institutional ethics involves institutions asking the same set of questions about their own activity. ${ }^{77}$

This approach is especially apt for understanding professional ethics. ${ }^{78}$ The very idea of a 'professional' derives etymologically from 'one who professes': that is, the act of professing what one stands for and living by it. ${ }^{79}$ On the integrity approach, professional ethics starts with the profession asking hard questions about its values, giving honest and public answers, and living by those answers. Doing so for a profession is more complex than for an individual. It requires leadership in posing questions and seeking members' answers. This process starts with the vital questions that must be asked of any profession: What is it for? Why should it exist? What justifies the profession to the community in which it operates given that the community provides privileges such as immunities, funding, and monopolies? Asking these questions involves a collective effort under the profession's own formal and informal processes. The resulting self-understanding can be called the organisation's Public Institutional Justification ('PIJ'). The PIJ provides an institution's raison d'être, and announces it to the world as - in part - a justification for the institution's existence and activities. ${ }^{80}$

A profession has integrity if it lives by its PIJ, which requires creating mechanisms that facilitate it living up to its publicly-declared values. ${ }^{81}$ These mechanisms include the debating, making and communicating of ethical codes; judgments about education, training and examinations; mentoring and advice; and, disciplinary and compliance mechanisms.

77 For further explanation of the links between personal and institutional integrity, see Hugh Breakey, Timothy Cadman and Charles Sampford, 'Conceptualizing Personal and Institutional Integrity: The Comprehensive Integrity Framework’ (2015) 14 Research in Ethical Issues in Organizations 1. This builds on Sampford's work outlined in Noel Preston, Charles Sampford and Carmel Connors, Encouraging Ethics and Challenging Corruption: Reforming Governance in Public Institutions (Federation Press, 2002).

78 See Michael Davis, 'Professionalism Means Putting Your Profession First' (1988) 2 Georgetown Journal of Legal Ethics 341.

79 Popular discourse and theoretical analysis highlight the links between professional and personal integrity: see Andrew Edgar and Stephen Pattison, 'Integrity and the Moral Complexity of Professional Practice' (2011) 12 Nursing Philosophy 94, 96; Sharon Dolovich, 'Ethical Lawyering and the Possibility of Integrity' in Tim Dare and W Bradley Wendel (eds), Professional Ethics and Personal Integrity (Cambridge Scholars Publishing, 2010) 125.

80 In each case, the profession's PIJ will centre on the constitutive activity and its contribution to specific public goods. For example, doctors would emphasise their contribution to health of the community and its members; nurses add the importance of frontline care. Engineers highlight their role in ensuring safe and effective buildings and infrastructure. Lawyers will speak of their role in contributing to the rule of law, the preservation of liberty, and justice under the law. Journalists inform the public about issues of critical importance - not least on the competing arguments about facts, values and the virtues of policies put by those seeking political office, so that citizens can effectively exercise their right to vote.

81 See Preston, Sampford and Connors, above n 77, ch 3; Breakey, Cadman and Sampford, above n 77. 


\section{Application to Corporate Ethics and Employed Professionals}

The integrity approach delivers two types of consequences for employed professionals. ${ }^{82}$ First, it requires each large organisation - in this case the employing organisation - to move through the same deliberative process of developing a PIJ, and then of putting in place decision-making, governance, recruiting and training regimes that empower the organisation to live up to that PIJ. Corporate ethics will thus start with the same collective questioning as professional ethics - asking hard questions about the corporation's values, giving honest and public answers, and living by those answers. Professionals may be in a position to facilitate this process of developing a PIJ, as it is one that will be more familiar to them. In cases where the professionals form a large part of the organisation (such as in a law firm or hospital), then a synthesis building on the professional values is likely to occur, as the institution's purpose parallels the values of the professions whose work it revolves around.

Second, the PIJ of any large organisation - even if it employs only a few professionals and focuses on a quite different purpose (eg, mining) - must allow room for its professionals to follow their profession's PIJ. Part of the organisation's PIJ must make explicit that its incentive-structures, pressures and processes allow and encourage its professionals to uphold their profession's PIJ. This is because the organisation's employees must be able to consistently uphold its PIJ. If those employees must - on the basis of their own integrity (already created through their professional membership) - live up to their profession's PIJ, then the organisation must ensure coherence between the two PIJs.

As well, the profession's PIJ is bound to be embraced by the local community: professions have longstanding PIJs that link to the promotion of goods of vital social interest. ${ }^{83}$ Given that the PIJ's fundamental purpose is to legitimise the organisation, it is hard to conceive how an organisation's PIJ could serve this purpose while publicly announcing the organisation aims to corrupt its employed professionals and the precious social values they secure. Without triggering a public relations backlash (at minimum), a corporation cannot publicly announce that, while employing professionals, it will prohibit them from behaving like professionals. Of course, an employing institution could still seek to secretly pressure its professionals into betraying their publicly stated values but such hypocrisy requires betraying its own integrity.

As such, pursuing institutional integrity ensures that employing organisations will ensure - and publicly demonstrate - that their professional employees retain their core professional ethical responsibilities.

\section{The Contract Approach}

\section{Application to Professional Ethics}

A fourth approach conceives professional ethics as formed on the basis of contract (or 'compact'/"licence'/'regulative bargain'). On this approach, the

\footnotetext{
82 For an in-depth application of the integrity approach to employed lawyers, see Sampford, 'Employed Lawyers', above n 33 .

83 See above $n 80$.
} 
professional code results from an agreement (whether formal, informal, explicit, implicit or tacit) between the professional and a larger group. The agreement might be a fair arrangement between the professional and his or her clients and prospective clients (who will only use the services of the professional if they meet standards of trustworthiness and reliability), between the professional and the wider society (who will only grant the professional the legal and social privileges required to fulfil their role if the professional performs on terms acceptable to the society) or between the professional and his or her professional community (who allow the professional entry into the occupation only on the condition that the entrant upholds standards that promote the profession's collective benefit and social standing).

In some respects, the contract approach parallels the integrity approach. However, the contractual approach is more dyadic in nature. The integrity approach centres on the question of personal values, asking: 'What do we stand for?' In contrast, the contractual approach involves different groups having a say over the resulting ethics, as they each ask: 'What is a fair deal for us?'

As Robert Veatch and others have argued, the contractual approach helps explain and justify many core professional duties. ${ }^{84}$ Communities and third parties will only allow the profession to enjoy its key legal privileges - especially its lucrative collective monopoly on service provision and epistemic expertise if it advances the public interest through ethical performance of its constitutive activities. Similarly, from their position of multidimensional vulnerability, clients will do everything they can to ensure professionals prioritise their interests through fiduciary responsibilities. And the profession itself has collective reasons to require individual professionals avoid bringing the profession into disrepute, if it is to allow them entry into the community of service providers.

\section{Application to Corporate Ethics and Employed Professionals}

The contractual approach to professional ethics extends to employed professionals in two distinct ways.

In the first way, the contractual approach can be applied directly to businesses themselves through the idea of the 'Social Licence to Operate' ('SLO'). This idea enjoys currency in recent debates from extractive industries to banking. ${ }^{85}$ The SLO acknowledges that a corporation can only legally exist within a community if it is legally recognised by that community or its sovereign representatives. Likewise, the corporation can only have property if that possession is recognised and protected by the community and its laws. SLO also recognises that corporations enjoy several particular privileges, ${ }^{86}$ including access to the community's consumers - the cash lifeblood for multinational corporations

\footnotetext{
84 See Robert M Veatch, 'Professional Medical Ethics: The Grounding of Its Principles' (1979) 4 Journal of Medicine and Philosophy 1; Breakey, 'Supply and Demand', above n 21; McGraw, above n 41.

85 See, eg, O'Brien et al, above n 32. SLO is analogous to the 'social contract' approach to government but is more practical and historical (with records of the reasons for company law in parliamentary debates and wider public discussion of the reasons for incorporation and their free access to our markets).

86 These include limited liability as well as the more particular privileges granted to certain industries or companies - such as the exploitation of mineral resources and the lender of last resort to banks.
} 
like Google, Apple and Starbucks. More generally, all organisations involve a combination of power, people and resources to secure a range of ends. That power can be used to further those ends, but it is always subject to capture and being used against the community. The American founding fathers recognised the risks with governments. ${ }^{87}$ They were not aware of the similar risks of joint stock companies, which were smaller and less numerous than those of our time..$^{88}$

Communities do not provide all the above benefits (let alone take the above risks) for the good of the corporations. They do it for the benefits flowing from the latter's incorporation. ${ }^{89}$ The SLO applied to corporate ethics would thus serve to (re)incorporate moral concerns into an array of business activities and processes..$^{90}$ While details will vary depending on the nature of the corporation, broadly speaking the resulting code for employed professionals would synthesise professional and corporate best practices, as both sectors move through the same contractual process of seeking and upholding their social licence to operate. While some differences may remain, this process could be expected to remove any major tensions between the two. This can be seen clearly in cases like banking and finance, where application of the SLO approach pushes the industry in a manifestly professionalised direction. ${ }^{91}$

The second way the contractual approach applies to employed professionals does not require the employing organisation itself to negotiate its social licence to operate. Instead, it merely reiterates that professional activities can only be performed under the condition that the professionals live up to their contractbased ethical standards. If the employing organisation wants these activities performed, then it needs to employ people who possess the socially-granted powers and privileges empowering them to perform those activities. The organisation thus has no choice except to employ the contractually-bound professionals, and to respect the ongoing obligations that alone empower those professionals to perform their constitutive activities.

\section{E The Excellence and Honour Approach}

\section{Application to Professional Ethics}

This final approach to professional ethic differs from the first four. All the preceding approaches took their bearings from standard elements of ethics (common morality, political legitimacy, integrity and contract). This final

87 See Alexander Hamiliton, James Madison and John Jay, The Federalist Papers (Oxford University Press, first published 1787, 2008 ed); Hugh Breakey, 'Dividing to Conquer: Employing the Separation of Powers to Structure Institutional Inter-relations' (2014) 12 Research in Ethical Issues in Organizations 29.

88 Their Glaswegian contemporary, Adam Smith, did recognise the risks and warned against them: Adam Smith, An Inquiry into the Nature and Causes of the Wealth of Nations (University of Chicago Press, first published 1776, 1977 ed).

89 This is not to deny that corporations should seek profits. However, like professionals, companies are expected to pursue profits in ways that benefit the community rather than damage it.

90 On taxation, see Hugh Breakey and Charles Sampford, 'Is Paying Tax Part of the Social License to Operate?' on Tax and Transfer Policy Institute, Austaxpolicy (11 July 2016) <http://www.austax policy.com/is-paying-tax-part-of-the-social-license-to-operate/>. 
approach instead looks to a more historically contingent possibility: the standards of excellence developed through traditions and practices that give rise to honour, pride and virtue.

The work of Alasdair MacIntyre provides a helpful theoretical foundation for this approach. In his influential After Virtue, MacIntyre put forward the idea of a practice, and linked it to a notion of 'internal goods':

By a 'practice' I am going to mean any coherent and complex form of socially established cooperative human activity through which goods internal to that form of activity are realised in the course of trying to achieve those standards of excellence which are appropriate to, and partially definitive of, that form of activity... ${ }^{92}$

In this way, a practice creates internal goods (emotional rewards and the attractive mode of life accompanying them) as participants strive for excellence in that practice..$^{93}$

But what does this have to do with professional ethics? Practices can promote virtue in several ways. We mention two here. ${ }^{94}$ First, the profession's constitutive ethic mentioned earlier in Part I has an important consequence: by laying down a specific but challenging activity as the constitutive activity of the profession's work, the ethic opens a space for excellence - an excellence that may be difficult for non-professionals to perceive, but whose parameters will be well-known to those within the field. Pursuing and achieving such excellence will require obeying the ethical constraints and purposes that constitute the activity. For example, one cannot experience the unique internal goods of the game of cricket if one cheats one's way to victory. In such a case, one could only enjoy the external material or social goods of being believed to have won. So too, the internal goods of professional activity require excellence to be pursued within the activity's ethical constraints (the exemplary lawyer cannot cheat his or her way to a good outcome) or in line with its socially beneficial purpose (an excellent engineer builds buildings with structural integrity; a brilliant surgeon does everything possible to save the patient). Simply, achieving excellence in the activity requires obeying the ethics inherent in the constitutive activity. To spurn the ethics is to stop performing the activity - and a fortiori to stop pursuing

92 Alasdair MacIntyre, After Virtue: A Study in Moral Theory (Duckworth, 1981) 175. We have already noted that ethics helps constitute professional activities (the 'constitutive activities' discussed earlier). MacIntyre makes the parallel point about standards of excellence: such standards are partially definitive of the activity. Combining the two points together, we can see that both ethics and excellence help constitute our understanding of these activities. Ethics and excellence are not contingently superadded to the activity. Rather, some such notions are already embedded within the very concept of the activity, meaning the pursuit of excellence implicates the performance of the ethics - and vice versa.

93 MacIntyre allowed that practices can be productive, meaning internal goods can attach to professional excellences: see Alasdair MacIntyre and Joseph Dunne, 'Alasdair MacIntyre on Education: In Dialogue with Joseph Dunne' (2002) 36 Journal of Philosophy of Education 1.

94 A further point is just worth flagging here, as the argument for it is complex. MacIntyre argued that the embedded character traits that empowered participants to achieve excellence in the practice necessarily (given the nature of practices, traditions and internal goods) gave rise to the development of classic virtues like courage and justice: MacIntyre, After Virtue, above n 92, 178. If so, then the pursuit of excellence would create recognisable virtues that could be applied more generally. 
excellence in that activity. The excellent professional thus incorporates ethical demands constitutively into their pursuit of excellence..$^{95}$

Second, for MacIntyre, practices, and their internal goods and subsequent virtues, take place in larger narratives that people and communities tell about their lives. ${ }^{96}$ This provides the inward-focused internal goods and excellences with an outward-integrating pressure to align with the stories a society tells about itself and its members. In the context of professionalism, the internal goods of (say) lawyering and journalism would need to align themselves with our larger socially-endorsed narratives about these practices and the lives that support them (consider concrete examples of such narratives, such as the fictional novel To Kill a Mockingbird for lawyers, or the based-on-real-events film Spotlight for investigative journalists). ${ }^{97}$ Such stories allow professional excellence to link up with wider social values, linking internal standards and external concerns.

MacIntyre's communitarianism ties in with other types of traditional reward systems, such as honour. In his work on The Honor Code, Kwame Anthony Appiah describes how a profession can create peers within an 'honour world' that allocates collegial respect to all and only other professionals who live up to the ethical standards..$^{98}$

\section{Application to Corporate Ethics and Employed Professionals}

The pursuit of the virtues required for excellence in the professional's signature activity - especially when it is steeped in tradition - carries potential for tension with corporate ethics. While MacIntyre's theory can be applied to businesses, corporate existence prioritises the external goods of prestige, status and (especially) profit. ${ }^{99}$ MacIntyre was not the only thinker to worry about the corrosive effects on virtue caused by the pursuit of power and profit. ${ }^{100}$ Even the flexibility required by effective management may impede the pursuit of excellence. In explaining why management is not a profession, Barker observes that management involves the flexible synthesis and integration of a wide array of activities, rather than excellence at a specific activity. ${ }^{101}$ For MacIntyre's system, these factors of profit-making and open-ended flexibility of action do not rule out the possibility of integrated goods of excellence - but they do make it less likely.

\footnotetext{
95 Breakey, 'Supply and Demand', above n 21, 15.

96 MacIntyre, After Virtue, above n 92, ch 15. This is the ideal. For discussion of the results of breakdown at this point (when social narratives cannot or do not support the practice's internal goods), see Hugh Breakey, 'Wired to Fail: Virtue and Dysfunction in Baltimore's Narrative' (2014) 11 Research in Ethical Issues in Organizations 51.

97 Harper Lee, To Kill a Mockingbird (Grand Central Publishing, first published 1960, 1988 ed); Spotlight (Directed by Tom McCarthy, Open Road Films, 2015).

98 Kwame Anthony Appiah, The Honor Code: How Moral Revolutions Happen (Norton, 2010) 191-4.

99 Ron Beadle and Geoff Moore, 'MacIntyre on Virtue and Organization' (2006) 27 Organization Studies $323,331$.

100 Alasdair MacIntyre, 'Social Structures and Their Threats to Moral Agency' (1999) 74 Philosophy 311. Appiah echoes this concern that entrepreneurial values like profitability and innovation are increasingly overwhelming professional honour: Appiah, above n 98, 195.

101 Barker, above n 37.
} 
Two conclusions follow. First, corporate life (especially outside professional firms and those capable of full alignment with professional excellences, such as newspapers encouraging journalist's ethics) cannot be expected to promote the same internal goods, excellences and virtues as professional practice. As such, the corporation may prove dismissive towards these crucial features of professional life, and create a peer environment quite distinct from the 'honour world' Appiah invokes.

Second, even if corporate practice does create internal goods in their own types of activities (ie, corporate excellence), these may not align with the types of excellences pursued by professionals. Conceivably, each practice could pursue their own excellences at cost to the other. The excellence of the manager or executive might require a decision-making authority over subordinates that strips from those subordinates the autonomy vital for the pursuit of professional excellence. ${ }^{102}$

On MacIntyre's theory, one saving grace may lie in his appeal to shared narratives, where each practice aims to situate its excellence in larger stories and modes of life, and so to develop its own account of the 'good life' in ways that match up with each other. As different ways of life integrate their stories with one another, each practice comes to terms with the others' demands for their own pursuit of excellence. Thus, larger narratives that incorporate stories about professional excellence alongside stories about corporate excellence, may work to align the two pursuits of excellence.

Large organisations employing professionals have a further, very pragmatic, reason to support professional honour systems and pursuits of excellence. Appiah highlights honour's power and efficiency as a moral motive for professional ethics:

people in an honor world automatically regard those who meet its codes with respect and those who breach them with contempt. Because these responses are automatic, the system is, in effect, extremely cheap to maintain. It only requires us to respond in ways we are naturally included to respond anyway. ${ }^{103}$

While a large organisation may sometimes be inconvenienced by the scrupulous ethic of its professionals, it stands to benefit considerably from their intrinsic trustworthiness and high standards of work - standards guaranteed by honour, rather than costly oversight and compliance measures. Such an organisation thus has pragmatic reason to encourage professional excellence in its employees.

\section{POTENTIAL SYNERGIES AND THE SUPREMACY OF THE PROFESSIONAL ETHIC}

This Part draws on all the foregoing types of ethical approaches, on the basis that they each provide their own insights into ethical life in societies and groups,

102 For a discussion of clashes between executive authority and internal excellences (in the context of police work), see Breakey, 'Wired to Fail', above n 96.

103 Appiah, above n 98, 191. 
and on how people conceive their moral duties, and can be motivated to comply with them. ${ }^{104}$

We have seen how the different ethical perspectives can apply directly to both corporate and professional ethics, allowing a common frame of reference to apply to both employer and employee. Though the specific codes of each may differ, by taking the larger ethical perspective, each agent should be able to conceive, understand, and respect the reasons for the ethical prescriptions governing the other, especially in their hallmark applications.

\section{A Supremacy within Professional Activities}

The foregoing Part's conclusion was that, for a corporation to have an employee provide a service that only a professional can perform, such an employee must be bound by the profession's ethical standards as he or she performs the service. When performing their constitutive activities - whether as an employee of a large organisation no less than as a sole-practitioner - the professional ethic must reign supreme over the professional's conduct. ${ }^{105}$ Simply, to do what a professional does, you need to have professional ethics. There are five reasons this is so, derived from the five ethical approaches canvassed above. ${ }^{106}$

In terms of common morality, the same vulnerabilities to their basic interests (and even their human rights) that face clients and third parties in solepractitioner professional activities can remain present with respect to employed professionals. Equally, the common-morality obligations of honesty undergird the need for professional trustworthiness and accuracy in corporate no less than professional contexts.

Regarding the role-requirements necessary to implement a legitimate social institution, we saw that professional ethics, when situated within larger systems, collectively contribute to the institutional realisation of vital social goods. To draw legitimacy from this collective contribution, these roles must be fulfilled by all professionals, irrespective of their employment context.

Turning to the integrity approach, we saw that any public statement of values (the PIJ) developed by a large organisation must necessarily include respect for the professional - and professed - ethics of its employed professionals, and so of their own integrity.

Considering the social contract, even if a large organisation itself does not go through the process of defending its social licence to operate, the organisation

104 See above n 61 and accompanying text.

105 In their analysis of some of the ethical issues that arise in areas that smear the distinction between private and public sectors, Hutton and Massey arrive at a similar outcome. They note the substantial overlap between public and professional ethics, but stress the priority required of the professional ethic, in order to allow other decision-makers to rely upon their expert advice: Hutton and Massey, above n 34.

106 One further point warrants mention. We saw earlier that professionals wield expertise in a particular knowledge domain that empowers them to make sophisticated judgements about practical cases. These judgments are difficult for non-professionals to appraise. Employers no less than clients can suffer from this incapacity to reliably appraise professional judgment - which makes intrusions on the professional's judgments even more ethically parlous. 
must accept that the powers and privileges that enable its employed professionals to perform their roles were socially dispensed to them only under condition that the entitlements would be used in accordance with ethical standards.

Finally, the pursuit of excellence within the professional 'honour world' provides employers with a pragmatic reason for encouraging high ethical standards and expertise in their employed professionals.

Consider several examples, highlighting the intuitive supremacy of the professional ethic as it pertains to the constitutive activity, and the ways in which this can restrict high-level decision-making and authority.

The individual doctor working in a hospital cannot expend unlimited resources and the hospital must decide the kind of services it offers. Such executive-level decisions must be taken institutionally and will involve many different professionals, as well as executives. Despite the role for aspects of both corporate and public sector ethics, such decisions cannot be simply determined by the owners of the hospital based solely upon their economic interests or even religious beliefs. It would be regarded as outrageous for someone to buy a private hospital and start to dictate the diagnoses, prognoses and treatments of patients, or to override the professional duties and decisions of the medical professionals (whether by individuals or professional oversight committees).

Like doctors, lawyers are increasingly likely to work for large organisations and this is particularly the case with the most able practitioners (other than barristers in divided professions). Even though more lawyers are working for governments, corporations, corporatised law firms or mixed professional firms, it would be considered outrageous for a corporate law firm to instruct employed lawyers on how they should fulfil their professional duties to the court.

It would be similarly problematic for the owners of a large construction company to instruct its engineers to sign off on decisions based on corporate priorities. The Challenger Space Shuttle disaster provides an unfortunately apt example of this case, where the lead engineer was asked to 'stop thinking like an engineer' and to make the decision to sign off on the launch's safety as a manager. ${ }^{107}$ In the event, the engineer acceded to his superior's pressure, and behaved as a manager while he was nominally performing the role of an engineer - to disastrous consequences. ${ }^{108}$

Unfortunately, existing media ethics provides something of a counterexample to the intuitive supremacy of professional ethics. It seems to be considered entirely within the rights of those who own newspapers or those who buy the bulk of the newspapers (by circulation) to dictate the editorial direction of those papers ${ }^{109}$ - and even to divert newspapers away from their fundamental role as newspapers. ${ }^{110}$ It is hard to see how this should be acceptable in a democracy that

107 Davis, 'Thinking Like an Engineer', above n 29, 152.

108 After all, the very reason the engineer had the capacity to sign off on the launch was because of his role and expertise as an engineer - rather than a manager.

109 Charles Sampford and Robyn Lui, 'Australian Media Ethics Regime and Ethical Risk Management' (2004) 19 Journal of Mass Media Ethics 86.

110 Sam Zell, the owner of Tribune Co, gave an illuminating 2008 speech to Orlando Sentinel staffers. Kathleen Parker outlines the gist: 'When he said he wanted to increase revenues by giving readers what 
thrives on oversight by the fourth estate, and why such papers' employees should enjoy the status and legal protections granted to professional journalists. ${ }^{11}$

\section{B Executive Decision-Making and Synthesis}

The five approaches surveyed above implied that within the professional's constitutive activities, their professional ethic should reign supreme. This requires that professionals should be involved in higher-level decisions that bear directly on their performance, and on the institutional pressures borne, and resources enjoyed, as they carry out those tasks within the organisation.

What, however, of executive decisions about overall institutional direction, and professionals' involvement in other areas of organisation decision-making? There is no one-size-fits-all answer to this question, which will depend upon the nature of the organisation, the types of decisions in question, and the professionals it employs. However, it seems plausible to think that the best option here will be for a synthesis of ethical values (rather than a prioritisation or simple aggregation).

Executive decision-making within large organisations will often differ from the narrower application of professional judgment in their area of expertise. Such decisions routinely call for a synoptic, integrated perspective that may differ significantly from the professional's hypersensitivity to the integrity of the constitutive activity and their pursuit of the client's interests. ${ }^{112}$ For this reason, professional judgment and ethics (outside the performance of their constitutive activity) cannot reign supreme over executive decision-making within the areas of executive discretion. As Figure One suggested, private enterprise and the public sector can emphasise different values (such as innovation and direct concern for the public interest) that are appropriate for their sectors and that must play a significant role in their overall decision-making. This outcome applies even to large organisations whose core business relates closely to the professionals' activity, such as mega law firms, hospitals and newspapers. Each of these organisations needs to respect the ethics of their professional employees. They also need to translate elements of that ethic into their executive decisionmaking (such as newspapers valuing objectivity not only in each discrete news story, but also in the overall consolidation and presentation of those stories into the newspaper as a whole). But such organisations also must heed the concerns raised by corporate and public sector ethics - such as a concern for employees' wellbeing and rights, respect for investors and shareholders'

they want, a female voice objected, "What readers want are puppy dogs." Zell exploded, calling her comment the sort of "journalistic arrogance of deciding that puppies don't count ... Hopefully we get to the point where our revenue is so significant that we can do puppies and Iraq, OK? [Expletive] you.": Kathleen Parker, 'In Defense of Newspapers', The Daytona Beach News-Journal (online), 13 August $2016<\mathrm{http}$ :/www.news-journalonline.com/opinion/20160813/kathleen-parker-in-defense-ofnewspapers $>$.

111 For detailed discussion, see Sampford and Lui, above n 109.

112 Barker, above n 37. 
interests, concern for local stakeholders, and environmental impact. ${ }^{113}$ Equally, values like innovation and accountability can be crucial at an executive level in a way they are not in the professional's autonomous realm (where innovation is concentrated on the profession's body of skills and knowledge, and accountability is primarily to the profession itself).

While the professional's ethics and judgment should not be prioritised over executive decision-making, integrating it into that thinking can provide the organisation with a valuable ethical resource. ${ }^{114}$ In many cases, the professional's ethical code gives the professional practical experience with: the processes of moving from general ethical principles to specific occupational duties (the common morality approach); the articulation of specific powers and responsibilities required to fulfil vital social functions (the role-requirements approach); the notion that special duties can derive from the specific privileges granted by a community (the contract approach); and with the process of developing and maintaining a public institutional justification and building the organisational elements capable of implementing it (the integrity approach). As well, the professional will be of considerable benefit to any organisations with at least quasi-professional elements, such as banking and financial services, where the professional's experience in dealing with fiduciary duties, vulnerable clients and third-party stakeholders can prove particularly valuable.

The professional may also bring a different perspective to the decisionmaking table. ${ }^{115}$ Earlier, in discussing the 'role-requirement approach' we saw how the professional ethic works to further the common good through established rules and collective practices. In contrast, both corporate and public service executives operate from a more direct standpoint, performing discrete acts that will straightforwardly deliver benefits. Since overall social wellbeing can be achieved both by direct approaches (through acts and initiatives) and indirect approaches (through rules and practices), the integration of the two perspectives at an executive level may prove ethically fecund.

All that said, some strategic level decision-making is likely to bear directly on the professionals' core responsibilities, and here prioritisation of the ethical code may be necessary. This will be particularly so for in-house lawyers, as executive decisions can implicate many issues within the lawyer's direct

113 This recommendation for pluralism accords with theorising that suggests that, in the context of management, lawyers' more legalistic approaches may benefit from being augmented by perspectives from corporate fields (like marketing or product development) that highlight stakeholder (shareholder, customer, public) concerns: see the discussion in Rosen, Parker and Nielsen, above n 53, 310-13, 321.

114 This can be especially true for lawyers, who are often well-placed to offer overall 'whole of business' ethical advice: see C Sampford and S Blencowe, 'Educating Lawyers to be Ethical Advisers' in Kim Economides (ed), Ethical Challenges to Legal Education \& Conduct (Hart Publishing, 1998) 315. See also Rosen, 'Serving the Organizational Client', above $\mathrm{n} 7$.

115 In general, the professional often has received formal training and education on ethics, is used to considering public interest and social institutions in an occupational context, and will likely possess the high level of moral reasoning that generally correlates with higher education: James R Rest, 'Morality' in Paul H Mussen, John H Flavell and Ellen M Markman (eds), Handbook of Child Psychology (John Wiley \& Sons, $4^{\text {th }}$ ed, 1983) vol 3, 556-629. 
bailiwick, including regulatory and contractual compliance, relations with external lawyers, conformity to company policy, employee relations and more. ${ }^{116}$

\section{Parallels in Public Sector Ethics}

The public service already enjoys a well-developed ethical tradition, dating back to the mid-nineteenth century, and sharing many values in common with the professional perspective. ${ }^{117}$ Much of what has been said above applies to public sector ethics, except that in these cases the closer alignment between public sector values and professional ethics will tend to reduce some of the potential tensions created by corporate ethics.

In particular, the public servant's overarching concern with working towards the public good in accord with settled rules carries clear synergies with the structure of professional ethics. ${ }^{118}$ Similarly, the teasing out of privileges, powers and responsibilities in accord with the role-requirements of a legitimate institution is a process that applies straightforwardly to the public sector indeed, it was in this very domain that theories of 'social contract' and institutional legitimacy began. ${ }^{119}$ And as Figure One showed earlier, while there are differences between the values of the public sector and professionals, there are enormous areas of overlap. In many cases, the professional and public service ethics therefore will be mutually reinforcing. ${ }^{120}$

That said, areas of tension do exist. While both professionals and the public service have commitments to the public interest, these are undertaken in different ways. The professional cleaves to the integrity of the constitutive task to provide valuable service to the client, and indirect but critical support to the public good that benefits the community. In contrast, the public servant can create and implement policy that directly benefits the larger public beyond the profession's specific public good. Both have the same ultimate goals, but each pursues the goal in a different way. This may mean that the public service employer wants to flexibly do what is required to directly benefit the public good. In comparison, the professional may seem rigid: only interested in serving the public good through the ethical practice of the constitutive activity.

116 For examples and discussion of such cases, see Gunz and Gunz, above n 18, 284-7. Their study suggested that, for lawyers, significant organisational-professional conflicts (at least of the type they considered) may be more likely to occur when the lawyer is close to strategic decision-making processes: at 265. Similar issues can arise for outside counsel: Rosen, 'Serving the Organizational Client', above n 7. Empirically, there is mixed support for the capacity of lawyers to impact on business compliance; indeed, sometimes they can encourage a legalistic, game-playing approach to regulation: see Christine E Parker, Robert Eli Rosen and Vibeke Lehmann Nielsen, 'The Two Faces of Lawyers: Professional Ethics and Business Compliance with Regulation’ (2009) 22 Georgetown Journal of Legal Ethics 201.

117 Grace and Cohen, above $\mathrm{n} 21,173$. Traditions of public service standards date back much further in other countries - especially China (which England consciously copied in reforming its own system).

118 Indeed, some works treat professional and public service ethics under the same heading: see, eg, Grace and Cohen, above $\mathrm{n} 21$.

119 Kipnis, above n 24. See, eg, Locke, above n 70.

120 We noted this overlap earlier in the context of 'frank and fearless advice'. See also above nn 54-5. Also, public sector ethics can rely on similar devices to encourage compliance, such as public oaths: see Fattah, above n 57, 69. 
The resolution of such tensions lies in a similar manner to the one adopted above with respect to corporate ethics, whereby the professional ethic must dominate in the professional's constitutive activities (which for lawyers includes identifying the powers public servants have, and what they can and cannot legally do), but a larger synthesis is necessary in other decision-making domains. The priority of the professional ethic in the constitutive activities remains for much the same reasons as previously outlined. In order to empower professionals to perform the very roles that the public sector requires of them, professionals possess key privileges and powers. Such entitlements are only acceptable to the public (via the contract approach), and only work collectively towards the public good (via the role-requirements approach), when they are performed in line with professional ethics. Equally, the public stance on practices and goals required by government organisations (in line with the integrity approach) cannot broadcast an intention to subvert the ethics of its professionals. ${ }^{121}$ In order to be able to live up to their professional duties in such cases, employed professionals working for the public service should, for their own protection, be subject to their code of ethics and the support and sanction of professional bodies. ${ }^{122}$

Outside the constitutive activities, different professionals within public organisations may need to develop specific professional codes which spell out the desired values and norms, and address potential challenges, temptations and dilemmas. The processes of developing these more fine-grained codes, and of synthesising the professional values into larger decision-making, should be easier in the public sector than it was in the corporate field, as the public servant's overarching goal is to benefit the general public, generating immediate sympathy with the larger purpose of the professional's core obligations. That said, in one respect this accord generates a different danger: namely, that the necessary processes are not performed, out of the mistaken view (perhaps of the executive public servant) that the codes must be wholly compatible. To the contrary, differences can arise in values, priorities and approaches, and they must be dealt with carefully.

Summing up, though in this case the larger institution's very raison d'etre is to serve the public, the professional's ethic must still be prioritised in all their

121 The 'common morality approach' will deliver similar results in cases where client and/or third-party vulnerability looms large, or when honesty and trustworthiness are implicated. So too, the 'excellence and honour' approach will carry the same benefit noted earlier regarding motivation for high standards of ethics and expertise.

122 This support is even more important with respect to corporate employed lawyers. Being part of a professional collective allows the professional's ethics not to constitute a competitive disadvantage to his or her employability: see Davis, 'Thinking Like an Engineer', above n 29. In the public service, this provides an advantage to lawyers who continue to hold practicing certificates when they work for government. That said, in certain historical cases, professional independence from a large organisational employer was not seen to automatically correlate with increased ethics. In his exploration of in-house counsel for large railroads in $19^{\text {th }}$ century United States, Rosen argues that the counsel's substantial decision-making authority, their negotiation of 'spider webs' of contractual obligation, and their need to govern the railroad's myriad stakeholders, gave them a stronger reputation for ethics than more 'independent' lawyers: Robert Eli Rosen, 'Rejecting the Culture of Independence: Corporate Lawyers as Committed to Their Clients’ (2010) 52 Studies in Law, Politics and Society 33. 
paradigm professional activities. Outside that purview, the ethical ideal will be synthesised in larger decision-making and values.

\section{OBJECTIONS}

Before concluding, we consider three objections against the foregoing arguments and the pre-eminence they assign to the professional ethic.

\section{A Employee's Contractual Obligations}

It may be objected that the salaried professional's contractual obligation to their employer provides a specific and binding moral obligation. However, we know of no employee contracts that incorporate either express or implied terms that require professionals to act contrary to their professional obligations. Courts would never imply such an interpretation and would be likely to read down any provisions that appeared to create such an obligation - unless they decided to simply strike the provision down as contrary to public policy. Few courts would consider it within the power of a corporation to instruct professionals to compromise the public good to which they are committed (and to which some, at least, have taken a public oath).

Generally, while the profession needs to collectively reflect on, and occasionally vary, the way they express the profession's public good and its derived values, norms and practices, these values are not subject to case-by-case renegotiation between individual professionals and their employers.

\section{B Loyalty}

Because it deals with social relationship and duties to others, and often taps into a genuine moral quid pro quo, loyalty to an employer, and to one's fellow employees, can feel like an overriding moral force. Yet loyalty has a worrying capacity to cloak misdeeds with a veneer of respectability. ${ }^{123}$

For a professional, loyalty can only be to an institution that behaves as worthy of loyalty - namely, one that respects and supports the professional's integrity and ethics. Whatever relationships or other support an institution offers, there can be no greater betrayal than of stripping workers' integrity, and forcing them into a situation where they are morally torn. ${ }^{124}$ After all, the employing organisation does not need to second-guess the professional's ethic. Nor are they being asked to deal with an employee's idiosyncratic moral convictions. The professional's morality is publicly known, easily accessible, socially vital, and long-established. An employing organisation that fails to protect the employed professional's pre-existing ethic does not warrant loyalty.

123 Greg Scherkoske, 'Integrity and Moral Danger' (2010) 40 Canadian Journal of Philosophy 335.

124 See, in the context of nursing, Kelly, 'Preserving Moral Integrity, above n 64. 


\section{Friedman's Corporate Ethics}

A final objection comes from a vision of corporate ethics that puts shareholder interests - and their interests in maximising profit specifically - as the overriding ethical obligation of corporate decision-makers. This view was popularised by Milton Friedman through his influential article 'The Social Responsibility of Business is to Increase Its Profits'. ${ }^{125}$ In crowning 'shareholder value' as the pinnacle of corporate ethics, a professional employed by a corporation may be thought to possess a duty to the shareholder to increase profits - even if doing so clashed with professional duties.

This view of corporate ethics is fundamentally mistaken. ${ }^{126}$ It assumes that corporations are a form of institutionalised sociopathy in which corporate profit is to be pursued irrespective of damage to the community. From the several ethical approaches described above in Part V, we have already seen an array of common-sense reasons why Friedman's ethic is so weakly supported.

First, common morality requires more than singular loyalty to employer/owner-trustees. Chief Executive Officers ('CEOs'), owners, managers and shareholders all hold - and should be assumed to hold - all the basic moral obligations of the common morality. As such, concern for shareholder's interest in profits, while an entirely proper consideration in executive decision-making, amounts to just one duty among many.

Second, Friedman's ethic stands in an uneasy relation to the above-noted moral value of integrity. The moral straitjacket Friedman puts on executive decision-making - demanding its exclusive attention to profitability - removes the possibility of business-leaders and corporate executives taking a public, settled and long-term stand on their company's guiding values. ${ }^{127}$ This illustrates a larger peculiarity of Friedman's approach: the single-minded attention to the shareholders rules out any genuine (rather than contingent and derivative) concern for other stakeholders. The ethic thus pays no heed to a businessperson taking a principled concern for delivering excellent service or products to their clients and customers. Thus, one of the most fundamental values of other ethical

125 Friedman, 'The Social Responsibility of Business', above $\mathrm{n}$ 44. Friedman's view needs to be distinguished from the political theory of libertarianism. Whatever else may be said on the topic, libertarianism is a political theory about political legitimacy and the proper scope of legal duties. Our focus here centres on moral duties, which may inhere irrespective of legal rights or obligations.

126 See Charles Sampford and Virginia Berry, 'Shareholder Values, Not Shareholder Value: The Role of "Ethical Funds" and "Ethical Entrepreneurs" in Connecting Shareholders' Values with Their Investments' (2004) 13 Griffith Law Review 115. Observe also the legal point that in most jurisdictions executives are bound by corporate law to work for the interests of the corporation. This is not the same as a Friedman-esque duty to work only for the shareholders' interests. A corporation is more than its shareholders; at minimum, the corporation's interests include its stated values and goals, its long-term sustainability, and its employees' welfare and safety. Still less does a duty to work for the corporation's interests require maximising shareholder profits (as distinct from shareholders' other interests).

127 Friedman's moral tunnel vision sunders the possibility of employed professionals cleaving with integrity to their profession's values, as decision-makers above them may at any time need to obey their overriding obligation to the shareholder by requiring the professional to breach their code. 
visions celebrating business and capitalism - genuine productivity ${ }^{128}$ - remains not only peripheral to Friedman's account, but antagonistic to it. In any case where shoddy design and intentional product failure (such as through 'planned obsolescence') will further the organisation's profits, Friedman's singular social responsibility will not only allow but require such deliberate betrayals of principled productivity.

Recalling the above discussion of contract, Friedman's ethic also fails to respect other contractual relations outside of the shareholder-executive arrangement. Professionals have contracts and oaths that morally bind them - and that remain binding when they are employed by corporations. Indeed, corporations themselves can have such duties: if such corporations wish to retain their social licence to operate, then they must accede to the contract-based demands of the society in which they practice. ${ }^{129}$

Ultimately, even Friedman himself wavered in advocating his signature thesis. In order to make his argument tenable, Friedman acknowledged that shareholders' desires to make money were to do so in accordance with the 'basic rules of society', including those of law and 'ethical custom'. Indeed, so far does Friedman depart from the single-minded prioritisation of shareholder profits, that some commentators have argued that is possible to construct a wide-ranging and multifaceted business ethic from his works. ${ }^{130}$ Whatever the prospects for such a construction, the important point for our purposes is that Friedman's straitened ethic of corporate social responsibility was so poorly justified that even Friedman himself could not hold it consistently.

Any coherent version of corporate ethics will be neither as simplistic nor sociopathic as Friedman's slogan thesis. So long as the corporate ethic is reasonably formed, it will cohere with - and be mutually supportive of - the professional ethic.

\section{CONCLUSION}

Though many professionals work for large and often profit-making corporations, they are employed as professionals. We have argued that their employers must realise that they cannot be expected or required, for the sake of higher profits or other benefits, to compromise their professional standards and their service to the public good. Even when professionals are employed by a large organisation like a corporatised law firm, a multinational corporation, the state, or an international body, the public good to which they are dedicated must remain at the centre of their professional life.

128 See, eg, Ayn Rand and Nathaniel Branden, The Virtue of Selfishness: A New Concept of Egoism, (Signet Book, 1964). Whatever else may be said of Rand's fictional 'Atlases', they were at least genuinely productive and had integrity - two traits inimical to Friedman's ethic.

129 O’Brien et al, above n 32.

130 Christopher Cosans, 'Does Milton Friedman Support a Vigorous Business Ethics?' (2009) 87 Journal of Business Ethics 391. 
How then can these outcomes be institutionalised into the internal arrangements of large organisations? Details of this next step lie beyond our scope, which aimed to set down the target of ethics reform, rather than the mechanisms to realise it. ${ }^{131}$ Still, in helping clarify the nature of the operative ethics in key contexts, we hope to have contributed to improved outcomes, if only because self-interest and partiality can hide within the spaces created by ambiguity.

Even so, the importance of explicit strategies for implementation can hardly be underestimated. Professionals require a high degree of autonomy and discretion in order to provide independent expert judgment in line with ethical standards. But as Grace and Cohen underscore: 'These are often the very qualities that organisations restrict, either intentionally or inadvertently'. ${ }^{132}$ Without attention in institutional design or decision-making processes, large organisations can all too easily stumble into treating professionals like other employees, unaware that their authority as employer can strip the professional of the very resource - professional independence - that they require to perform their role. As Parker et al observe: 'There is potential for management systems that are not explicitly designed to encourage ethical behaviour to actually discourage it'. ${ }^{133}$

Aspects of this question of institutional implementation and support for professional ethics are addressed elsewhere in the literature and in this Issue. ${ }^{134}$ Here we confine ourselves to two general points, and one specific recommendation.

First, the supremacy of the professional ethic in the constitutive activity highlights the importance of a strong, well-resourced and proactive professional organisation, capable of working with - and when necessary standing up against - large corporate and even state employers. Professionals need to be able to voice their professional ethic with confidence, assured of the knowledge that other employed professionals would also resist lowering their standards. ${ }^{135}$

Second, once an institution has gone through a process to settle its ethical values (often through a procedure akin to that noted earlier on the 'Integrity Approach' in Part V(C)), the resulting ethical values need to infiltrate every part of the organisation's functioning. ${ }^{136}$ Bringing ethics from principle into action requires reforming and revisiting: internal arrangements, incentive-

131 This conclusion accords with what has been termed 'values-based governance', where the ethical values form one part of - but also provide the overall direction and purpose to - a larger integrity system that includes institutional reform and legal regulatory measures: see Sampford, 'Institutionalising Public Sector Ethics', above n 39; Preston, Sampford and Conners, above n 77, 162-98.

132 Grace and Cohen, above n 21, 157.

133 Parker et al, above n 34, 182.

134 See below n 137.

135 Davis, 'Putting Your Profession First', above n 78. See also the limitations of cases (like engineering) where professional accreditation is not legally required for practice: Hutton and Massey, above n 34, 25.

136 See Sampford, 'Institutionalising Public Sector Ethics', above n 39; Preston, Sampford and Connors, above n 77, ch 3; Fattah, above n 55. That said, institutional and workplace pressures should not be presumed to be totalising. Bévort and Suddaby describe a case study where professionals enjoyed considerable flexibility in interpreting professional versus managerial scripts: Bévort and Suddaby, above n 2 . 
structures, promotion requirements, decision-making processes, rules and guidelines (including aspirational codes of ethics and disciplinary codes of conduct), internal and external checks and balances, recruitment practices, education, mentoring and training (and engagement with external educational organisations), problem-setting, stakeholder consultations, shareholder communications, performance metrics, industry awards and honours, transparency and flows of information, workplace scripts, ethical climates, compliance practices and regulatory approaches, fragmentation or consolidation of professional tasks, and more. ${ }^{137}$

Material and other constraints can hamper such sweeping changes, and reform efforts must be realistic. A poorly-funded legal aid organisation, or a financially struggling corporation already wrestling with changes to its regulative environment, may despair of possessing the time, effort, leadership and expense required to work through a process of constructing shared values and implementing them throughout its organisation.

This leads us to our one specific recommendation, which any institutional employer can perform as a helpful first step. That is, the serious and public recognition by the professional's employers that they only employ professionals to do what professionals can ethically do. This recommendation of an explicit public assertion of respect for the employed professionals' ethical obligations may seem obvious enough as a 'first step' (though obviously not a panacea). However, it bears notice that such recognition does not appear in any major code, principle, charter, declaration, or aspirational statement of ethical business practice or corporate social responsibility. This includes the 'Brussels Declaration for Strengthening Ethical Business for Shared Value and Shared Benefits', the PRI's 'Principles for Responsible Investment', 'The Earth Charter', the 'Triple Bottom Line' approach, the OECD Guidelines for Multinational Enterprises, the 'ISO 26000 Guidance on Social Responsibility', 'The Equator Principles' and the 'Caux Round Table Principles'. ${ }^{138}$

Voluntary codes laying down corporate duties with respect to human rights also make no mention of respect for the ethics of employed professionals, despite the fact that professionals routinely work in the service of human rights (eg, in areas of education, knowledge, health, and due process of law). Yet the United

137 See Parker et al, above n 34; Hugh Breakey, 'Building Ethics Regimes: Capabilities, Obstacles and Supports for Professional Ethical Decision-Making' (2017) 40 University of New South Wales Law Journal 322; Preston, Sampford and Connors, above n 77, ch 3; Sampford, 'Institutionalising Public Sector Ethics', above n 39; Rosen, 'Serving the Organizational Client', above n 7.

138 World Forum for Ethics in Business, Our Principles: Brussels Declaration (2015) $<\mathrm{http} / / /$ wfeb.org/ourprinciples/ $>$; The Earth Charter Commission, 'The Earth Charter' $2<\mathrm{http}$ //earthcharter.org/invent/ images/uploads/echarter_english.pdf $>$; Principles for Responsible Investment, The Six Principles https://www.unpri.org/about/the-six-principles>; Timothy F Slaper and Tanya J Hall, 'The Triple Bottom Line: What Is It and How Does It Work?' (2011) 86 Indiana Business Review 4; Organization for Economic Cooperation and Development, OECD Guidelines for Multinational Enterprises (OECD Publishing, 2011); International Organization for Standardization, 'ISO 26000: Guidance on Social Responsibility’ (1 November 2010) <www.cnis.gov.cn/wzgg/201405/P020140512224950899020.pdf>; The Equator Principles Association, 'The Equator Principles' (June 2013) < http://www.equatorprinciples.com/resources/equator_principles_III.pdf >; Caux Round Table, 'Principles for Responsible Business' (2009) <www.cauxroundtable.org/view_file.cfm?fileid=143>. 
Nations ('UN') Guiding Principles on Business and Human Rights and the Amnesty International's Human Rights Principles make no mention of professions. ${ }^{139}$

If all these aspirational documents fail to pay heed to the professions' vital roles (especially of lawyers, accountants and auditors) in the proper functioning of moral capitalism, then it is little wonder we find corporate executives themselves failing to accord such duties priority. ${ }^{140}$

The lack of explicit acknowledgement also makes it easier for professionals themselves to rationalise their ethical failings. Consider for example the behaviour of the Australian Wheat Board's (AWB) in-house lawyers as they helped facilitate and hide bribes to Saddam Hussein's Iraq in defiance of UN sanctions. As Hall and Holmes discuss in their exploration of lawyers' ethics and rationalisation, the AWB lawyers could avail themselves of a wide range of potential blame-mitigating factors, including their pursuit of the client's interests, the wider economic benefit to Australian wheat farmers and even the 'national interest', and the disaggregated process of decision-making (and even contractwriting) that shunted responsibility away from the AWB legal department. ${ }^{141}$ Without question, fixing the ethical culture at the AWB would have required a sweeping and multifaceted reform process. ${ }^{142}$ But even so, any initiatives that served to reduce the ambiguity surrounding the proper role of employed professionals (in this case, the in-house counsel) would have helped limit the scope for, and ease of, the professionals' self-serving rationalisations.

In summation, those who employ professionals should expect high professional standards from their employed professionals. If they want someone to do professional work for them subject to the highest standards of professional ethics, then they have chosen the right person. If such organisations want the professional to work contrary to the ethics of the profession, they should discover that in hiring a professional they have made the worst (and hopefully the last) employment decision of their lives.

139 Office of the United Nations High Commissioner for Human Rights, 'Guiding Principles on Business and Human Rights: Implementing the United Nations "Protect, Respect and Remedy” Framework' (United Nations, 2011) <http://www.ohchr.org/Documents/Publications/GuidingPrinciplesBusinessHR_EN.pdf>; Amnesty International, 'Human Rights Principles for Companies' (January 1998)

$<$ https://www.amnesty.org/en/documents/act70/001/1998/en/>.

140 The duties should also be made explicit in order to clarify to shareholders (and potential shareholders) the corporation's understanding of its moral position with respect to its treatment of employed professionals. This allays Friedman-esque concerns about executives going off on a moral frolic of their own, and empowers institutions for responsible investment to factor in the company's contribution to the socially vital gatekeeper roles played by employed professionals.

141 Kath Hall and Vivien Holmes, 'The Power of Rationalisation to Influence Lawyers' Decisions to Act Unethically' (2008) 11 Legal Ethics 137.

142 See above nn 136-137 and accompanying text. 